\title{
Identity and group conflict
}

\author{
Article
}

Accepted Version

Creative Commons: Attribution-Noncommercial-No Derivative Works 4.0

Chowdhury, S. M., Jeon, J. Y. and Ramalingam, A. (2016) Identity and group conflict. European Economic Review, 90. pp. 107-121. ISSN 0014-2921 doi:

https://doi.org/10.1016/j.euroecorev.2016.02.003 Available at https://centaur.reading.ac.uk/73400/

It is advisable to refer to the publisher's version if you intend to cite from the work. See Guidance on citing.

To link to this article DOI: http://dx.doi.org/10.1016/j.euroecorev.2016.02.003

Publisher: Elsevier

All outputs in CentAUR are protected by Intellectual Property Rights law, including copyright law. Copyright and IPR is retained by the creators or other copyright holders. Terms and conditions for use of this material are defined in the End User Agreement.

\section{www.reading.ac.uk/centaur}

\section{CentAUR}

Central Archive at the University of Reading

Reading's research outputs online 


\title{
Identity and Group Conflict*
}

\author{
Subhasish M. Chowdhury ${ }^{\mathrm{a}}$, Joo Young Jeon ${ }^{\mathrm{a}}$ and Abhijit Ramalingam ${ }^{\mathrm{b}}$ \\ ${ }^{a}$ School of Economics, Centre for Behavioural and Experimental Social Science, and Centre \\ for Competition Policy, University of East Anglia, Norwich NR4 7TJ, UK. \\ ${ }^{\mathrm{b}}$ School of Economics, and Centre for Behavioural and Experimental Social Science, \\ University of East Anglia, Norwich NR4 7TJ, UK.
}

This version: January 30, 2016

\begin{abstract}
We experimentally investigate the effects of real and minimal identities on group conflict. In turn we provide a direct empirical test of the hypotheses coined by Amartya Sen that the salience of a real identity escalates conflict but that of a mere classification would not do so. In a baseline treatment, two groups - East Asians and Caucasians - engage in a group contest, but information on the racial composition of the groups is not revealed. In the minimal identity treatment each group is arbitrarily given a different color code, whereas in the real identity treatment the race information is revealed. Supporting Sen's hypotheses, we find that compared to the baseline, free-riding declines and conflict effort increases in the real identity treatment but not in the minimal identity treatment. Moreover, this occurs due to an increase in efforts in the real identity treatment by females in both racial groups.
\end{abstract}

JEL Classifications: C91, C92, D03, D74, J15, J16

Keywords: Group Conflict, Identity, Race, Gender

\footnotetext{
* Corresponding author: Subhasish M. Chowdhury (s.modak-chowdhury@uea.ac.uk)

This research was partially supported by a grant from the Centre for Behavioral and Experimental Social Science at the University of East Anglia. We thank three anonymous referees, Carmen Bevia, Yan Chen, Werner Güth, Shaun Hargreaves Heap, Dongryul Lee, Roman Sheremeta, seminar participants at the University of East Anglia, Kyung Hee University, and the participants at the $1^{\text {st }}$ London Experimental Workshop, $6^{\text {th }}$ Indian Experimental Economics Conference in Kolkata, Korean Econometric Society Annual Conference in Yang Yang, ESA World Congress in Zurich, Stockholm School of Economics workshop on 'Conflict: Theory and Evidence', Young Researchers Workshop in Contests and Tournaments in Barcelona, the Autumn workshop at the Max Planck Institute - Jena for useful comments; and Zoe Bett, Emanuela Lezzi, Ailko van der Veen and Jiwei Zheng for research assistance. Any remaining errors are our own.
} 


\section{Introduction}

Conflict between groups is omnipresent. Group members expend costly resources in such conflicts in order to gain material benefits, or to achieve social recognition, or to avoid a loss. Examples include racial conflict, conflict relating to language, religion or culture, political competition, collective rent-seeking, to name but a few. Such group conflicts are costly for the individual group members and often costly also for the society. ${ }^{1}$ It is hence not surprising that researchers across disciplines continue to study the reasons leading to such conflict, and possible ways to eradicate them. A component that is often seen to be common in initiation and escalation of various group conflicts is group identity. In this paper we consider this particular aspect and investigate the effects of the salience of specific types of identities on group conflict. We consider a real identity and a minimal identity in defining groups, and compare their effects on conflict relative to a situation in which no identity is made salient.

In his seminal work, Sen (2007) introduces the relationship between the salience of an identity and conflict. Sen considers 'identity' as an attribute that provides a 'strong-and exclusive-sense of belonging' to a group. He hypothesizes that in certain situations, when a particular identity (e.g., religion or race) becomes salient, it can then engender conflict and can even lead to its escalation. He further introduces the concept of 'classification' and differentiates the same from 'identity'. A classification (e.g. one's shoe-size or one's time of birth) is a mere categorization that is 'cheap' and does not necessarily have 'durable importance'. It is also often interpreted as a minimal identity. As a result, when an identity or a classification determines the concept of a group, the salience of the (real) identity increases conflict but that of a minimal identity (classification) does not. ${ }^{2}$ In this study we conduct a laboratory experiment to investigate the relationship between the salience of identities and conflict. We ask the following questions: Is there empirical support for Sen's hypotheses about the effects of identity on conflict? Does real identity initiate and instigate conflict more than does a mere classification (minimal identity)? Is the effect of identity symmetric across agents?

We run a group contest experiment with a group specific public good prize. In this game group members expend individually costly effort for their group and the sum of all group

\footnotetext{
${ }^{1}$ The earliest documented group conflict resulting in fatalities was between 14,000 BC and 12,000 BC in Nubia (present-day Sudan) in which at least 59 people died (Kelly, 2005). Almost 15,000 years later, in the last century, the conflict between the Hutu and the Tutsi populations in Rwanda, Burundi and Uganda claimed more than a million lives. Even when fatalities are not involved, group conflicts often create costs such as long run tension and hatred, intentional destruction of property, expense of resources on unproductive defense activities, etc.

${ }^{2}$ Note, however, that when a classification gains durable importance then it may be as important as a real identity. We do not consider such classifications in our analysis, and return to this issue in the discussion.
} 
members' efforts influences the probability of winning the prize. Irrespective of the outcome of the contest, all players lose their efforts - resembling conflict situations in the field. Furthermore, irrespective of the individual effort expended, every member of the winning group wins the prize - again, replicating various field situations. We rely on the theory by Katz et al. (1990) and the experimental procedures in Abbink et al. (2010) for the basic structure of the experiment, and introduce the concepts of identity and classification within this structure.

We employ three treatments. In the baseline, two three-player groups - one consisting of East Asians, and the other consisting of Whites (Caucasians) - engage in the group contest, but no information about the group composition is revealed. In the treatment capturing classification or minimal identity the same experiment is run, but each group is arbitrarily given a different color code. In the real identity treatment the racial compositions of the groups are revealed. We introduce race as the real identity since historically race provides one of the strongest and most exclusive-sense of belonging. To ensure that the design for the minimal identity treatment is as close as possible in spirit to the definition of classification by Sen (2007), the dimension of the categorization would have to be 'cheap' as well as 'non-durable' and easy to make salient. A random color code meets all these criteria and hence the same is implemented in the 'classification' treatment. In the baseline we did not provide any sense of categorization or belonging. Whereas the color codes provide the salience of an explicitly cheap and durably unimportant 'categorization'; in the baseline treatment (given the frame and the instructions) this categorization remains absent, and hence is not salient.

The relationship between identity and several other behavioral outcomes is well examined in the literature. Sherif et al. (1961), Turner (1978), and Tajfel \& Turner (1979) among others investigate this broad topic in Social Psychology. Sherif et al. (1961) is a milestone in both identity and conflict research areas. They conduct a field experiment in which two groups of boys engage in a series of group competitions. To our knowledge, this is the very first 'group contest' research as well as the first group identity research in any branch of social science. The boys engaged in pre-contest group activities to induce group identity. It is found that over the time of the contests, the group members become hostile towards out-group members. Since this seminal study, social psychologists have studied the role of identity in prejudice (Brewer, 1999), discrimination (Sassenberg \& Mummendey, 2003), stereotypes (Steele et al., 2002), among others.

In the area of conflict as well, there have been important contributions by Tajfel \& Turner (1979), Jackson (2002) and Tajfel (2010, ch. 2, 3, 10), among many others. Within Economics, Sen (1985) himself studies the effects of identity on coordination. However, the 
exploration of the effects of identity in the economics literature starts with the seminal study by Akerlof \& Kranton (2000). Since then, a series of studies have emerged. ${ }^{3}$ Chen \& Li (2009) stand out by employing a minimal identity paradigm similar to the idea of 'classification' as explained in Sen (2007).

Existing field studies or laboratory experiments in social psychology and in economics have shown that an introduction of an identity elicits in-group out-group discrimination. ${ }^{4}$ It has further been shown that group identity can be formed in terms of inequality (Esteban et al., 2012a, b), or communication (Cason et al., 2012) and that such a group identity can be exploited to invoke stereotypes (Shih et al., 1999), to manage diversity (Eckel \& Grossman, 2005), or to solve hold-up problems (Morita \& Servátka, 2013). To explore identity related conflicts, existing experimental studies often employ games such as the prisoner's dilemma, the dictator game or the public good game that examine 'conflict of interests' in agents, but are not designed to replicate group conflict situations in which group members expend costly resources to gain something. Thus, although the hypotheses coined in Sen (2007) are often discussed in various studies, there exists no research testing them, or to find the effects of different levels of identity on behavior. In this study we investigate, in a controlled setting, the effects of the salience of a particular identity and classification on 'Conflict' and provide direct empirical tests.

Since we consider a public good prize in the group contest setting, the set of research closest to the current one are in the area of the effects of identity in social dilemma such as a public good or a threshold public good game (Brewer \& Kramer, 1986; Solow \& Kirkwood, 2002; Eckel \& Grossman, 2005; Croson et al., 2008; Drouvelis \& Nosenzo, 2013; Charness et al., 2014; Gumen, 2015). In each of these studies, at least in one treatment a specific identity is invoked in a social dilemma setting; and in general, such identity increases contribution. These studies often find heterogeneous effect of the identity among subjects.

In our experiment, we find that in all the treatments subjects expend significantly more effort than is predicted by Nash equilibrium. However, efforts are significantly higher in the real identity (but not in the minimal identity) treatment than in the baseline treatment. Furthermore, these results are obtained both due to a reduction in free-riding (expending zero effort), and an increase in efforts in the real identity treatment. Neither racial group, as a whole,

\footnotetext{
${ }^{3}$ For example, Robinson (2001), Akerlof \& Kranton (2002, 2005, 2008, 2010), and Basu (2005) analyze the theoretical background and Fershtman \& Gneezy (2001), Goette et al. (2006), Deck et al. (2009), Chen \& Li (2009), Hargreaves Heap \& Zizzo (2009), Chen \& Chen (2011), Kranton et al. (2013), Chen et al. (2014), Stoddard and Leibbrandt (2014) pursue field and experimental studies in related areas.

${ }^{4}$ See, e.g., Tajfel \& Turner (1979) from social psychology; and Benjamin et al. (2010), Deck et al. (2009), Hargreaves Heap and Zizzo (2009), Klor and Shayo (2010), Cason et al. (2012) from economics.
} 
behaves differently from the other. However, regardless of race, females expend significantly higher effort than males, and (in the line with the social dilemma literature) the difference widens when the real identity is revealed.

There are existing studies in the literature that investigate the effects of identity on conflict behavior. Some studies (e.g. Kranton et al., 2012) employ a variation of a dictator game whereas some others (e.g. Gumen, 2015) employ a public good game. Furthermore, there are existing social preference studies on identity - as cited above - that find higher levels of ingroup preference with identity. Hence, it is important to distinguish this study from the existing ones, as well as emphasize the importance of the findings of the current study.

Understandably, the reasons for conflict are intertwined with the social preferences of the agents. However, it is not established in the literature that the preference will definitely result in a higher conflict level for identity but not for classification. To our knowledge, ours is the first study in the identity literature that examines the effects of the 'levels' of identity (none to classification to real) on human behavior. Furthermore, we believe that we introduce a new and more appropriate framework in the relevant identity literature to analyze conflict. In any conflict agents expend irretrievable resources to gain something, and whereas only the winners gain, irrespective of the result everybody lose their expended resources. Only a contest game is appropriate to capture this feature. No other games can capture this basic and intrinsic feature of conflict. Take the public good game for example: these are very useful games to understand social dilemmas between own and societal interest and hence, are apt for analyzing 'conflict of interest', but not 'conflict'.

Hence, in this paper we provide a framework that is the most appropriate in a laboratory setting to analyze conflict, and introduce identity in such a framework for the first time. We also introduce different levels of identity and provide with an empirical test of the hypotheses coined by Sen (2007). We confirm systematically, instead of simply conjecturing, that real identity indeed increases the initiation and the level of conflict, whereas a mere classification does not. The results make a two-fold contribution. They support Sen (2007)'s argument that a salient real identity initiates (in terms of the reduction of free-riding) and escalates (in terms of higher positive effort) conflict. Moreover, a minimal identity (classification) does not increase conflict significantly - further supporting his hypothesis. Investigating gender differences, we conclude that the effect of identity, at least in this set-up, is asymmetric across gender. This study also contributes to the literature on identity itself by incorporating and analyzing conflict, and show how various types of identity affect conflict behavior. 
The rest of the paper is organized as follows. Section 2 provides a theoretical background of the conflict model we use. Section 3 explains the design of the experiment. Section 4 presents the results and Section 5 concludes.

\section{Theoretical background}

We study a group contest in which multiple groups compete for a prize. Group members expend costly effort that constitutes the 'group effort'. The group effort determines the group's likelihood of winning the prize. In particular, a group's probability of winning the prize is equal to the group's effort divided by the total group effort of all competing groups.

Let the number of groups competing for the prize be $n(\geq 2)$ and the number of (riskneutral) group members in each group be $m(\geq 2)$. Each player $i$ in each group $g(=1,2, \ldots n)$ has the same endowment, $e>0$, from which he/she can expend effort $x_{g i} \in[0, e]$. Any effort expended by a member of group $g$ increases the likelihood that group $g$ will win the prize. Any endowment not expended remains with player $i$.

The group effort of group $g, X_{g}$, is the sum of the effort expended by all members of group $g$, i.e., $X_{g}=\sum_{i} x_{g i}$. Let the total group effort by all groups competing for the prize, i.e., by all $\mathrm{nm}$ players, be $X=\sum_{g} X_{g}$. The probability with which group $g$ wins the prize, $p_{g}$, is determined by a lottery contest success function (Tullock, 1980) and is given by

$$
p_{g}=\left\{\begin{array}{ll}
X_{g} / X & \text { if } X \neq 0 \\
1 / n & \text { otherwise }
\end{array} .\right.
$$

The prize is a group-specific public good prize, i.e., each member of the winning group earns the prize regardless of their level of effort expended. Let the common prize value be $V>$ 0 . The losing groups receive a prize of 0 . The expected payoff of player $i$ in group $g$ is

$$
\pi_{g i}=p_{g} V+\left(e-x_{g i}\right),
$$

where the first term is the expected value of the prize and the second term is the part of the endowment that player $i$ kept with them. From Katz et al. (1990) it can be shown that there exist multiple equilibria and individual equilibrium efforts cannot be characterized. ${ }^{5}$ However, in any equilibrium, the group effort for each group is

$$
X^{*}=V(n-1) / n^{2} \text {. }
$$

In a finitely repeated game, the sub-game perfect equilibrium prediction is that each group will expend $X^{*}$ in each repetition of the stage game.

\footnotetext{
${ }^{5}$ Katz et al. (1990) consider an additive group production technology. There are other technologies such as weakest-link (Lee, 2012), best-shot (Chowdhury et al., 2013), or a mix (Chowdhury and Topolyan, 2016) that are considered in the literature. But we restrict our attention to the most popular and obvious one as described above.
} 


\section{Experimental Design and Hypotheses}

\subsection{Design and Procedures}

The experiment consists of a finitely repeated contest between two groups of three groupmembers each, and the core design is very similar to the design implemented in Abbink et al. (2010). In the experiment, each member of each group is endowed with 60 Experimental Currency Units (ECUs) which they can allocate to a group account or to an individual account. Once all individuals make a decision, the lottery contest success function is used to determine the winner. Each member of the winning group is awarded 40 ECUs. Subjects are then informed of the total ECUs in their group account, the total ECUs in the other group's group account, which group has won the prize, and their individual earnings in ECUs from that period. Three-player groups and aggregated information feedback ensure no in-group reputation effect.

This contest is repeated for 20 periods. Subjects cannot use past earnings in future periods and receive a fresh endowment of 60 ECUs in every period. At the end of the session, each subject is shown their individual earnings in ECUs in each of the 20 periods. All subjects are then paid for the same 5 periods chosen randomly at the rate of $25 \mathrm{ECUs}$ to $1 \mathrm{GBP}$. In terms of the theoretical model presented above, the parameters of the contest in our experiment are $n=2, m=3, e=60$ and $V=40$. Hence, the equilibrium prediction in our experiment is that group effort for each group is 10 ECUs, i.e., $X^{*}=10$, in each of the 20 periods. ${ }^{6}$

In all treatments 9 subjects from each of the two racial cohorts, East Asians and Whites (Caucasians), participate in a session. Within each cohort, subjects are randomly and anonymously assigned to groups of three. Two groups - one from each racial cohort - are then randomly and anonymously paired. Thus, all three members of a group are from the same racial cohort and the two competing groups are composed of subjects from the two different racial cohorts. ${ }^{7}$ The matching within and between groups remains fixed throughout a session.

It is important to clarify our subject-recruitment strategy due to the specific nature of the experiment. All the subjects were students at the University of East Anglia, UK. In this

\footnotetext{
${ }^{6}$ Note that the endowment given to the subjects is higher than the Nash equilibrium level of group effort $(e>$ $X^{*}$ ), so the theoretical prediction across treatments remains as the Nash equilibrium level of effort. Baik et al. (2016) show that even when $e>X^{*}$, if the endowment is different across treatments then it can affect observed effort level across treatments due to behavioral reasons. But, since in our case the endowment is the same across treatments and we are interested in treatment effects, this does not affect our analysis.

${ }^{7}$ Since there are various real identities that can be considered as the focus of conflict, it is important to narrow down on a specific identity. Young (1982) argues that: "( $r$ )ecent history suggests that the major pattern of conflict cohere around two organizing principles: class and ethnicity". Indeed existing studies have shown that race or ethnicity remains one of the most important factors in various social conflicts across the globe (e.g. Esteban \& Ray, 2012a, b; Reynal-Querol, 2002). Hence, in this paper we consider race as the real identity.
} 
university there are similar proportions of White Caucasian and East Asian students, who together constitute around $90 \%$ of the student population. Hence, it is convenient to implement racial identity in the laboratory, and to recruit White and East Asian subjects, without raising suspicion - as almost all other experiments have similar racial compositions in subject cohorts. We sent recruitment emails only to East Asian and White subjects from the university subjectdatabase through ORSEE (Greiner, 2015). We filtered using participants' self-reported country of citizenship (Northern Europe, Western Europe, USA, Canada etc. for Whites; and China, Japan, Korea, Hong Kong, Macau, Taiwan etc. for East Asians) and their name. The second criterion, name, filtered out students whose name do not seem to be one of the two racial categories (e.g. Latino students from the USA or British students of Indian origin). We recruited more subjects than required, and randomly chose 9 subjects from each race at the start of a session. The remaining recruited subjects received a turn-away fee. We also ensured that ethnically the subjects entering the laboratory are indeed Whites or East Asians. In only one case a Black student with Western name from the USA showed up and received a turn-away fee; we did not include her in that session.

We employ three between-subject treatments and four sessions in each treatment. In the Baseline (no identity) treatment no information about the group composition is revealed. In the instructions we use phrases such as 'your group' and the 'group you are matched with'. In the Color ('classification' or 'minimal identity') treatment the same experiment is run, but each group is arbitrarily given a different color code - either Green or Blue. The instructions in this treatment mention, at the beginning, that everyone in their group is of the same color code and that everyone in the group they are matched with is of the other color code. All the remaining parts of the instruction remain the same as in the Baseline. To test if there are any interactions between race and the color code, in half the Color sessions, East Asians were in the Green group while Caucasians were in the Blue group (Green-Blue). The color codes were reversed in the other half of the sessions (Blue-Green). In the Race (real identity) treatment the racial compositions of the groups are revealed. The subjects are informed at the beginning of the instructions that everyone in their group is of the same race and that everyone in the group they are matched with is of the other race. The remaining parts of the instruction stay the same as in the Baseline. The instructions are available in the Appendix.

The experiment involved a total of 216 subjects who could participate in only one session. No subject had prior experience in participating in a contest or in an identity experiment. Sessions were computerized using z-Tree (Fischbacher, 2007), and was run by an East-Asian and a White research assistant. At the beginning of each session, instructions were 
handed out and were read aloud by an experimenter. No other information, including details of race, was disseminated. Subjects were required to answer a quiz before the experiment began. Each session lasted $\sim 60$ minutes and average earning per subject was $\sim 16$ GBP.

\subsection{Hypotheses}

Given the design and the discussions above, we construct the following hypotheses about behavior in the experiment. Whereas Hypotheses 1 and 2 come directly from Sen (2007); Hypothesis 3 comes as a corollary to his work. The effect of the salience of a particular identity might not be the same for all individuals, since their background, norm and other condition may affect the behavior. In our context, this means race-specific social norms may affect how individuals from a particular race react to the salience of race. However, there is no ex-ante reason to consider this effect to be stronger for a particular race. Hence we state a no-difference of the effects of identity across races in the last hypothesis.

We test Hypothesis 1 and Hypothesis 2 both at the group level as well as the individual level, and Hypothesis 3 at the individual level.

Hypothesis 1 (Sen, 2007: Identity). Effort expended in the Race treatment is significantly higher than the effort expended in the Baseline treatment.

Hypothesis 2 (Sen, 2007: Classification). Effort expended in the Color treatment is not significantly different from the effort expended in the Baseline treatment.

Hypothesis 3 (Homogeneous effect). Change in individual effort expended between treatments is the same across racial groups.

\section{Results}

Each treatment has 72 subjects, but the subjects receive feedback on group efforts of their group and of the competing group after every period. Hence, each competing pair of groups (consisting of 6 subjects) forms an independent observation. We first test if a particular color has an effect on behavior in the Color treatment. We run a random-effects regression of individual efforts on a constant, one-period lagged own effort, one-period lagged effort of the rival group, a time trend and a color dummy and found no significant differences in behavior between these two color labels ( $\mathrm{p}$-value for the dummy $=0.372$ ). Hence, in all our subsequent 
analyses, we pool data from the Green-Blue and the Blue-Green sessions under the Color treatment. There are thus 12 independent observations in each treatment.

\subsection{Group-Level Analysis}

We first investigate if there are differences between the treatments at the group level before moving to an individual level analysis of the reasons for any treatment differences. Table 1 presents summary statistics of the mean (averaged over all 20 periods) per-period group effort by competing pairs of groups.

Table 1. Mean (St. Dev.) of Competing group pairs' Efforts

\begin{tabular}{cccc}
\hline Treatment & Baseline & Color & Race \\
\hline Average & 34.869 & 38.006 & 46.008 \\
Standard Dev. & $(13.161)$ & $(9.607)$ & $(17.401)$ \\
\hline
\end{tabular}

Observe that the average effort in any treatment is higher than the effort predicted by the Nash equilibrium (10). Wilcoxon signed-rank tests confirm this result (p-value $<0.001$ for all treatments). This, however, only reiterates the robust phenomenon that overdissipation, i.e., expending more effort than the Nash prediction, occurs in this type of contest experiments (Dechenaux et al., 2015). A more interesting observation arises when we compare the group efforts across treatments. Mean group efforts over all the 20 periods shows a monotonic increase from Baseline to Color to Race. Specifically, the increase from the Baseline to the Race treatment is from 34.869 ECUs to 46.008 ECUs, or an increase of $31.95 \%$.

To investigate if the patterns observed above are driven by behavior only in particular periods or in particular effort range, we plot the mean group efforts over periods (Figure 1) and their empirical CDFs over the effort range (Figure 2). For all treatments, overall efforts decrease over time, but still stay above the equilibrium effort (the red horizontal line in Fig. 1). Efforts are also distributed over the whole effort range, but the Race treatment seems to stochastically dominate the Baseline. Furthermore, the mean group efforts over period for each racial group shows similar pattern as in Figure 1; and so do the distributions of groups efforts for each racial group with Figure 2. Hence, we do not present the race specific figures. 
Figure 1. Mean group effort over period by treatment

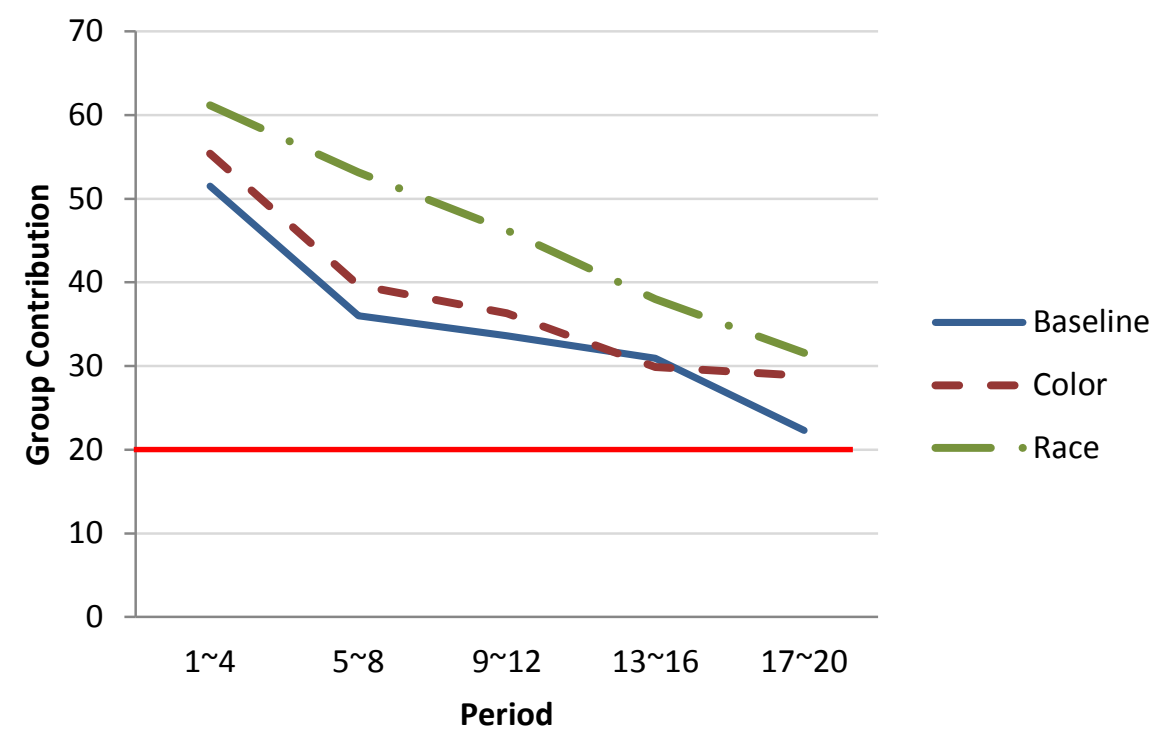

Figure 2. Empirical CDFs of group effort

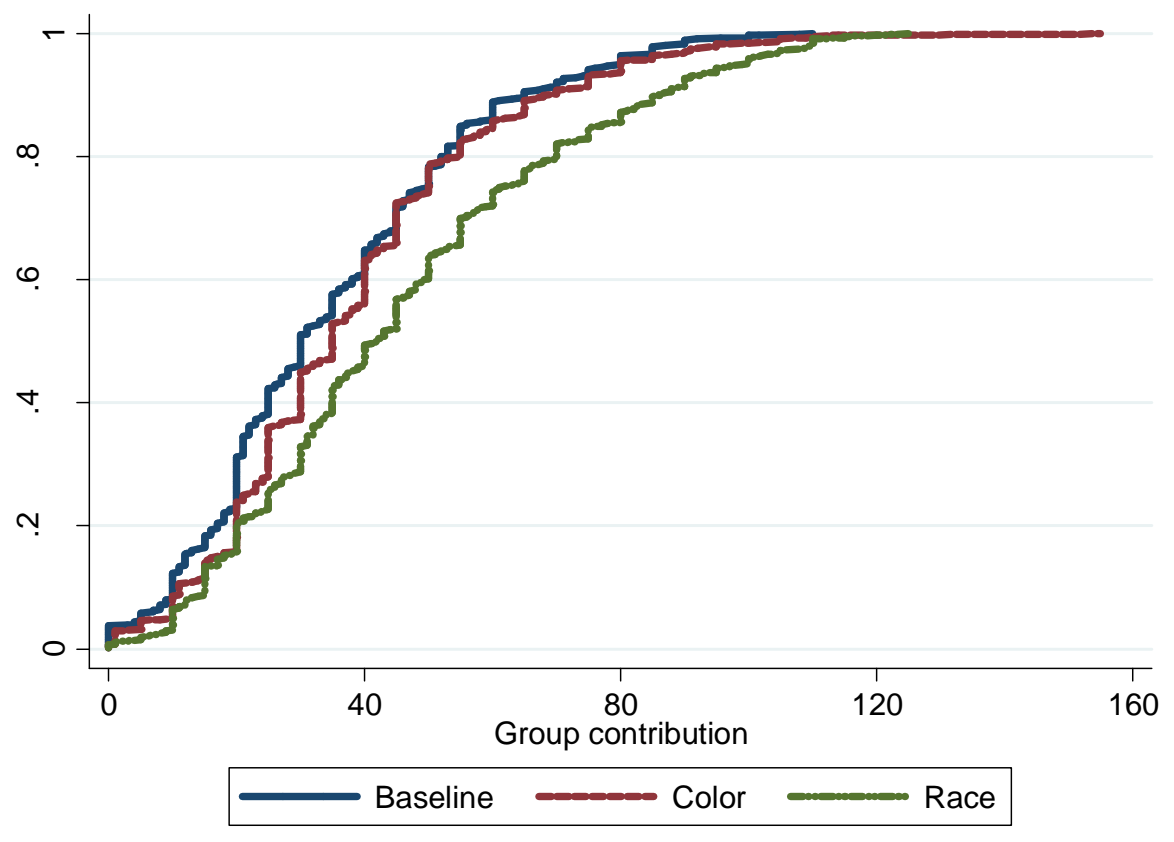

Figure 1 reinstate that group efforts in the Race treatment are always higher than the efforts in the Baseline or in the Color treatments. The comparison between the Color and the Baseline treatments, however, is not that obvious. Efforts in the Color treatment remain higher than, although very close to, the efforts of the Baseline treatment. Figure 2 shows that while the efforts are distributed over the whole range, the effort levels are higher in the Race treatment compared to the Baseline and probably also to the Color. 
We next test whether the differences noted above are statistically significant with a Kruskal-Wallis test. It confirms that the efforts distributions are different in the different treatments ( $\mathrm{p}$-value $<0.001$ ). To further examine treatment differences and the direction of the differences, we first run pairwise Mann-Whitney tests at the group-pair level. It shows a significant difference at the $10 \%$ level between the Race and the Baseline treatments (p-value $=0.083$ ), but no difference between the Color and the Baseline treatments ( $\mathrm{p}$-value $=0.326$ ). We then run a panel random effects regression that uses multiple observations for each group, one for each period. The dependent variable is group $g$ 's effort in period $t$, and the independent variables are two treatment dummies for Race and Color. We also control for the group's own effort in the previous period, the other group's effort in the previous period and a time trend.

In this equations (and also in the two similar equations later) we estimate robust standard errors clustered on independent competing pairs. The equations present regression estimates, and $* * *, * *$, and $*$ respectively indicate significance at the $1 \%, 5 \%$ and $10 \%$ level. Figures in parentheses are robust standard errors.

$$
\begin{aligned}
\text { Group effort }_{\mathrm{gt}}= & 10.811^{* * *}+3.088^{*} \text { Race }+0.747 \text { Color } \\
& (2.340) \quad(1.646) \quad(1.311) \\
& +0.591^{* * *} \text { Group effort } \mathrm{g}_{\mathrm{t}-1}+0.156^{* * *}{\text { Rival's Effort } \mathrm{t}-1-0.332^{* * * *} \text { Period }}(0.051)
\end{aligned}
$$

No. of obs. $=1368$. No. of groups $=72$. No. of competing group-pairs (clusters) $=36$.

This regression confirms the observations above. The dummy for the Race treatment is positive and significant ( $\mathrm{p}$-value $=0.061$ ) but the dummy for the Color treatment is not ( $\mathrm{p}$ value $=0.569$ ); groups expend about 3.1 ECUs more per period in the Race treatment than in the Baseline treatment. This gives our first result.

Result 1: Group efforts are higher in the Race treatment than in the Baseline treatment. But there is no difference between group efforts in the Color and in the Baseline treatment.

Since efforts are contributed in the contest in order to overcome the opponent's efforts and to win the prize, the efforts can be used as a measure of the level of conflict. Result 1 thus confirms Hypothesis 1 and Hypothesis 2 at a group level. First, introducing a real identity increased the level of conflict by a group. Second, introducing a minimal identity (classification) did not affect the level of conflict significantly. It can also be observed that group efforts are positively correlated to lagged own and opponent group efforts, and are negatively correlated to time trend. These again confirm earlier findings as in Abbink et al. (2010) that group efforts 
decline over time and that efforts are increasing in their own past efforts and in those of the competing ones.

This result, however, comes with a caveat. While the current design is enough to answer our specific research questions (Hypotheses 1 and 2) as coined by Sen (2007), the results cannot tease out the effects of identity on in-group cooperation versus out-group hate. Hence, the most we can conclude from these results is that a real identity has a direct effect on parochial altruism (Choi \& Bowles, 2007; Halevy et al., 2008; Abbink et al., 2012, Weisel \& Bohm, 2015, Weisel and Zultan, 2016). That is, the incremental effect of identity in conflict efforts can come either through an increase in group cooperation for the love of own group's identity, or through an increase in hate for the other group's identity. It is observed in the literature (as discussed in the introduction) that in a public good game an introduction of identity can indeed increase contribution due to in-group love. But to incur out-group hate, one will have to face a threat from the out-group (Weisel \& Bohm, 2015). Since in the current design the prize is a group specific public good, and the efforts of the out-group reduce the likelihood of one's obtaining the prize, both effects can be in action. Although it will not be an apples-to-apples comparison, one can compare the effect of identity in this setting with that in a public good game. It can be observed that an introduction of the real identity increased the effort level by about $32 \%$ in the current study (Table 1). Comparing this with the results of Solow and Kirkwood (2002, p. 408 - both genders: Strangers vs. Community) who find about an $8 \%$ increase, or Charness et al. (2014, p. 328 - NoGrNoTy vs. GrNoTy) who find about a $26 \%$ increase in contribution in a public good game with the introduction of identity, ${ }^{8}$ it appears that both components of parochial altruism are in effect in the current study.

\subsection{Individual-Level Analysis}

We next investigate the reasons for higher efforts in the Race treatment. To do so, one would have to analyze the data at an individual level. We are primarily interested in the overall level of effort exerted in the conflict. Note that, due to the public good nature of the prize, it is possible for the individual subjects to free-ride completely on group-members by expending zero effort, or partially by expending low effort. So, the increase in overall effort in the Race treatment can occur due to several reasons: either subjects are free-riding less under the Race treatment, or they are expending more efforts, or both. To investigate this, we first analyze free-

\footnotetext{
${ }^{8}$ We report these numbers only to provide an idea of the effect of identity in contests compared to a public good setting. There are other studies who either do not state explicitly the average effects (e.g. Eckel and Grossman, 2005), or the setting is very different to make a comparison (e.g. Gumen, 2015) and we do not report them here.
} 
riding, and then effort contingent upon not free riding. Establishing the effect of racial identity in both the cases, we return our focus to the overall effort level (including zero effort) and test whether Result 1 is robust across racial groups (Hypothesis 3). To do so, we analyze overall effort level at the individual level - for each of the racial groups.

\subsubsection{Effects of identity on individual free-riding and effort decisions}

We first study the extent of free-riding (expending zero efforts) by individual players in each treatment. Note that, each subject can free-ride once in a period, i.e., between 0 and 20 times in the whole experiment of 20 periods. Figure 3 summarizes the instances of treatmentwise free-riding by subjects through the empirical CDFs of the incidence of free riding. The horizontal axis in Figure 3 shows the number of times a subject can possibly free-ride, and the vertical axis shows the corresponding proportion of actual free riding by treatment. It can clearly be observed that the incidence of free-riding is less in the Race treatment compared to in the Baseline. But there does not appear to be a large difference in the incidence of free-riding between the Color and the Baseline treatment.

Figure 3. Empirical CDFs of the incidences of free-riding

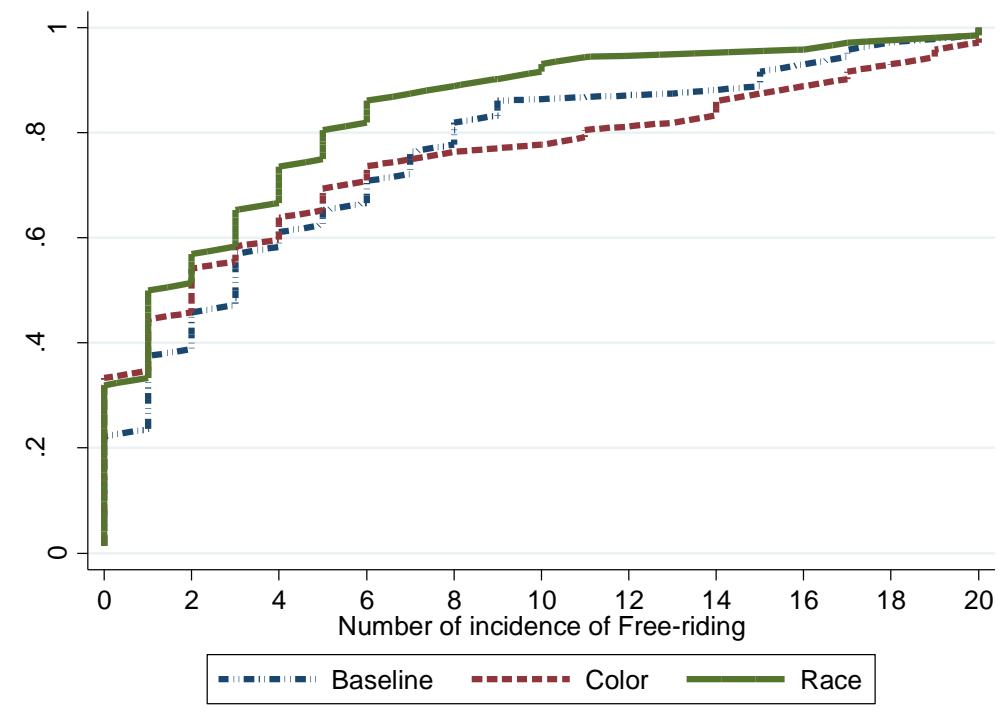

To test this observation of treatment effect statistically, we run an individual-level regression. Note that we can consider the 20 periods as 20 trials in which free-riding might or might not occur. In such a case a binomial regression would be the appropriate model to estimate. The dependent variable is the number of instances of free-riding by an individual whereas the independent variables are the Race and the Color treatment dummies, a dummy for East Asian and a dummy for females. The results are reported in Table 2. 
Table 2. Binomial regression on the incidence of free-riding

\begin{tabular}{lc}
\hline \multicolumn{2}{l}{ Dependent variable: Number of } \\
Free-ride by an individual \\
\hline Color & 0.004 \\
& $(0.050)$ \\
Race & $-0.082^{*}$ \\
& $(0.047)$ \\
E. Asian & 0.009 \\
& $(0.034)$ \\
Female & $-0.079^{*}$ \\
& $(0.044)$ \\
Constant & $0.283^{* * *}$ \\
& $(0.052)$ \\
\hline Observations & 216 \\
\hline
\end{tabular}

$* * *, * *$, and $*$ respectively indicate significance at the $1 \%, 5 \%$ and $10 \%$ level. Figures in parentheses are robust standard errors.

Table 2 above shows that compared to the Baseline, the incidences of free-ride declines in the Race treatment, but not in the Color treatment. The above results suggest that participation in conflict, in terms of reduction of free-riding, increases with the salience of a real identity but not of a classification. These findings, further supporting Hypotheses 1 and 2, are summarized in Result 2.

Result 2: The incidence of free-riding is lower in the Race treatment than in the Baseline treatment. Color treatment does not show such a difference.

Given the findings that overall efforts (including free riding) are higher and free-riding itself is lower in the Race treatment compared to the Baseline, it will be of interest to test whether the effort level, contingent upon not free-riding, is also higher in the Race treatment. To do so, we first examine individual effort levels by treatment; but consider only the cases in which an individual has spent a positive effort. The summary statistics are reported in Table 3. Not surprisingly, the number of instances of strictly positive contributions are higher in the Race treatment. Furthermore, whereas the increase in overall conflict effort (including zero effort) from Baseline to Race treatment was $31.95 \%$ (Table 1), conditional upon positive effort, this increase is from 15.369 ECUs to 18.434 ECUs, or 19.94\%. Hence, the increase due to a reduction in free-riding is $12.01 \%$. 
Table 3. Individual effort level contingent upon positive effort

\begin{tabular}{cccc}
\hline & Baseline & Color & Race \\
\hline Mean & 15.369 & 17.018 & 18.434 \\
St. Dev. & $(10.699)$ & $(11.717)$ & $(12.025)$ \\
No. Obs & 1,089 & 1,072 & 1,198 \\
\hline
\end{tabular}

To test whether the observation above is statistically significant we run a hurdle model in which the first decision is whether to spend positive effort, and the second decision is to decide upon the level of effort given that the effort is positive. Specifically, in the first stage a random effect Probit model and, in the second stage a random effect Tobit model is implemented. As expected, and as observed in the descriptive statistics above, in the second stage the Race treatment - even after controlling for no free-riding in the first stage - has a significant and positive effect on the effort level. The results are reported in Table A1 in the Appendix.

\subsubsection{Identity and the overall individual level of conflict effort}

After establishing that identity reduces free-riding and increases effort contingent upon not free-riding, we now shift our focus back to the overall level of conflict. We analyze the effects of the treatments on the individual level of conflict first by each racial group and then by gender. ${ }^{9}$ In Table 4 we present means and standard deviations of individual efforts per period (including zero effort) for East Asian and White subjects.

Table 4. Mean (St. Dev.) Individual Efforts per period separated by race

\begin{tabular}{cccc}
\hline & Baseline & Color & Race \\
\hline \multirow{2}{*}{ White } & 11.539 & 11.510 & 14.788 \\
& $(11.454)$ & $(11.466)$ & $(12.269)$ \\
\multirow{2}{*}{ East Asian } & 11.707 & 13.828 & 15.885 \\
& $(11.367)$ & $(13.443)$ & $(13.592)$ \\
\hline \multirow{2}{*}{ All } & 11.623 & 12.669 & 15.336 \\
& $(11.407)$ & $(12.543)$ & $(12.954)$ \\
\hline
\end{tabular}

\footnotetext{
${ }^{9}$ We also test whether average group efforts between racial groups are different within treatment. We calculate differences of group efforts between paired groups and run a Wilcoxon signed rank test to test if this difference is zero. For all the treatments, we find no significant difference of bids between White and East Asian groups.
} 
Table 4 shows that individual efforts are higher in the Race treatment than in the Baseline (15.336 ECUs vs. 11.669 ECUs). Overall, the effort in the Color treatment is not much higher (12.669 ECUs) than in the Baseline. Since individual effort decisions are not independent, it is not possible to run non-parametric tests aimed at race categories. Hence, we once again employ panel regressions to test if the overall treatment differences seen in Table 4 are statistically significant. The equation below presents the estimates of an individual random effects regression of efforts on treatment dummies and controls. The additional independent variables are lagged effort of the rival group, the individual's one-period lagged effort, a time trend (period), and race and gender dummies.

$$
\begin{aligned}
& \text { Individual effort }_{\text {it }}=3.397^{* * *}+1.156^{* *} \text { Race }+0.321 \text { Color } \\
& \begin{array}{lll}
(0.759) \quad(0.569) \quad(0.473)
\end{array} \\
& +0.547^{* * *} \text { Own effort } \mathrm{i}_{\mathrm{t}, \mathrm{t}-1}+0.056^{* *} \text { Rival's Effort }_{\mathrm{t}-1}-0.128^{* * *} \text { Period } \\
& \text { (0.040) (0.016) (0.027) } \\
& +0.485 \text { EastAsian }+0.998^{* * *} \text { Female } \\
& \text { (0.476) (0.468) }
\end{aligned}
$$

No. of obs. $=4104$. No. of subjects $=216$. No. of competing group-pairs (clusters) $=36$.

It can be clearly observed that the individual efforts are indeed higher in the Race treatment than in the Baseline; the treatment dummy is positive and significant at the $5 \%$ level. Subjects expend 1.16 ECUs more effort per period in the Race treatment than in the Baseline treatment. However, although the efforts in the Color treatment are higher than in the Baseline, the difference is not statistically significant. We then run three further regressions with pairwise treatment data - between Baseline and Race, Baseline and Color, and Race and Color treatments. The results are reported in Table A2 in the Appendix. As can be seen from the table, the outcomes remain the same. These findings are summarized in the following result.

Result 3: Individual efforts are higher in the Race treatment than in the Baseline treatment, but they are not higher in the Color treatment compared to the Baseline treatment.

Results 1, 2, and 3 provide formal support for Hypotheses 1 and 2 at a group as well as at an individual level. We now test Hypothesis 3, i.e., whether these results are robust across racial (and other demographic) groups.

Note that the significant coefficients of lag effort of the rival group and lag effort of own group are potentially very useful to the interpretation of results as indicating rivalry and conflict. Namely, increases in effort as a reaction to higher effort of the rival, may suggest that subjects are not simply trying to determine the optimal level of effort. If the significance of 
these coefficients are treatment dependent, then it can shed light on out-group hate versus ingroup love. To test this we run a random effect regression with two sets of interaction terms: treatment and lag effort of rival group, and treatment and lag effort of own group. We find that there is no significant difference between coefficients of lag choice of rival groups in either the Baseline or the Race treatments. Hence we cannot make definitive conclusions about subject behavior. The regression results are summarized in Table A4 in the Appendix. ${ }^{10}$

Table 4 shows that the increase in efforts in the Race treatment is not very different between the two racial groups. Whereas East Asians increase efforts marginally for both types of identities, Whites increase efforts only in the real identity treatment but not in the minimal identity. The regression reported above suggest no significant difference in effort levels between the racial groups. This matches with our earlier finding (footnote 8) that average group efforts within treatment between the East Asian and the White group are not different. Note, however, that the regressions do not test for differences in effort levels between genders or racial groups in the different treatments. We investigate this issue below.

Although the East Asian indicator is not significant, the coefficients for the Female indicator in the above equation is significant. But the regression does not specifically test for differences in effort levels between genders or racial groups in the different treatments. Therefore, we now investigate whether the effects of identities are heterogeneous across genders. To do so, first in Table 5 we present mean and standard deviation of individual bids by male and female in all treatments.

Table 5. Mean (St. Dev.) Individual Efforts per period separated by gender

\begin{tabular}{ccccc}
\hline & & Baseline & Color & Race \\
\hline \multirow{3}{*}{ Male } & Mean & 11.523 & 11.313 & 12.407 \\
& St. Dev. & $(11.599)$ & $(11.655)$ & $(11.307)$ \\
& No. Subjects & 35 & 38 & 36 \\
\hline \multirow{3}{*}{ Female } & Mean & 11.718 & 14.184 & 18.265 \\
& St. Dev. & $(11.229)$ & $(13.312)$ & $(13.814)$ \\
& No. Subjects & 37 & 34 & 36 \\
\hline \multirow{3}{*}{ All } & Mean & 11.623 & 12.669 & 15.336 \\
& St. Dev. & $(11.407)$ & $(12.543)$ & $(12.954)$ \\
& No. Subjects & 72 & 72 & 72 \\
\hline
\end{tabular}

\footnotetext{
${ }^{10}$ We run several robustness checks with further specifications. We check whether the results are concentrated in a particular time period. As can be observed from Figure 1, we find that it is not the case and qualitative results remain the same. Moreover, we implemented own lag effort and lag of (own group - own individual) effort, and the treatment effects still remain the same.
} 
The table suggests that higher efforts in the Race treatment are driven mainly by higher efforts by female subjects. Efforts of female subjects increase from 11.718 ECUs in the Baseline treatment to 18.265 ECUs in the Race treatment. Females expend more effort in the Color treatment (14.184 ECUs) than in the Baseline, but the increment is not as high. Males do not show such behavior. This is confirmed by the regression in the equation above: females expend about 1 ECU more effort than their male counterparts.

We further investigate this gender effect by estimating an individual-level random effect panel regression with interaction between treatments and gender dummies. The dependent variable is once again individual efforts and the independent variables include those in the equation in the regression above along with the interaction terms.

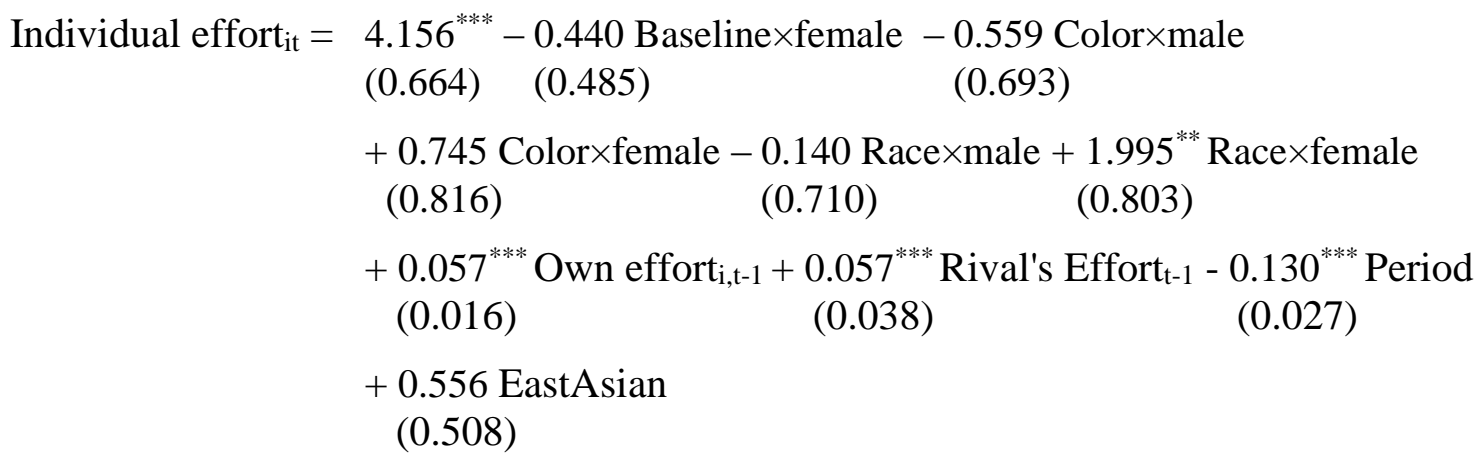

No. of obs. $=4104$. No. of subjects $=216$. No. of competing group-pairs (clusters) $=36$.

This regression shows that the higher individual efforts in the Race treatment are essentially driven by higher efforts expended by females in that treatment. Relative to males in the Baseline, females in the Race treatment expend significantly higher effort. The other controls show no difference in results from the previous analyses. We further investigate whether the higher effort of females in the Race treatment occurs due to an effect of real identity or whether it is merely a context-driven behavior (Croson and Gneezy, 2009). We include an interaction of female dummy with Race treatment in the regression above, which it turns out to be significant but the Color dummy interacting with genders remain insignificant. Hence, we conclude that identity itself induces higher efforts by females.

We, again, run pairwise treatment effects regressions that are reported in Table A3 in the Appendix. These pairwise regressions reaffirm that the results hold for the Race treatment but not for the Color treatment. Additionally, it shows that females expend significantly higher effort in the Race treatment compared to the Color treatment. All these findings are summarized in the following result. 
Result 4: The higher efforts in the Race treatment relative to those in the Baseline treatment are driven by the higher efforts expended by female subjects. Females also expend significantly higher effort in the Race treatment compared to the Color treatment. However, there is no significant difference in efforts expended by females between the Color and the Baseline treatment, neither there is any difference in effort expended by racial groups.

Result 4 allows one to reject Hypothesis 3 in the dimension of gender, and asserts that although the conflict behavior are robust across racial groups, it is not so across gender. This result, that females' increment in effort due to the revelation of identity is higher than their male counterparts, is apparently puzzling. This is because in war, terrorism etc. we expect to see the opposite. This, however, conforms to the general observations of higher effort exertion by females in contests (Price and Sheremeta, 2015), that females are more prone to the winner's curse (Casari et al., 2007), and that identity brings in more competitiveness among females in a laboratory setting (Cadsby et al., 2013). Moreover, this matches the existing general observation that there are differences between the decisions of men and those of women (Eckel and Grossman, 2008).

More importantly, although female participation is not often observed in physical conflicts such as war or riots, it is still possible to find external validation for our result. It is well understood in the Psychology literature that males are more aggressive and competitive in situations in which the conflict is physical and can sustain physical harm. But in non-physical conflict situations females are either more aggressive than their male counterparts or there is no significant gender difference (Eagly and Steffen, 1986; Bjorkqvist, 1994; Hyde, 2005). Since a laboratory contest game reflects a frame of conflict without inflicting physical harm, it enables females to be more aggressive in this game than male subjects. Combining this with the evidence that group identity has stronger effects on female contributions (Croson et al., 2008), we believe that the current results can explain incremental verbal hostility, non-physical intimidation, violation of norms by females when group identity becomes prominent.

\section{Discussion}

We investigate the effects of identity and classification in group conflicts in an experimental setting. We employ a group contest with no identity, real racial identity and a minimal identity (classification) and find that compared to Baseline conflict is significantly higher in the real identity treatment but not in the minimal identity treatment. This is due to both initiation (less free-riding) and escalation (expending more effort) of conflict in the real identity case. Hence, 
we provide a direct empirical test of the hypotheses coined by Sen (2007) that (i) the salience of a real identity can initiate and escalate conflict; but (ii) that of a classification will not do so and find support for both. Adding to his hypotheses, we find that the increase in conflict in a laboratory contest setting does not arise due to the behavior of a particular race, but due to the increase in efforts by females across racial groups in this setting.

These results contribute to the literature on conflict and as well as to the literature on identity. Existing identity studies rely on experiments on 'conflict of interest' to analyze conflict. Our experiment pushes that front in a laboratory setting, and provides specific results. To our knowledge, this is also the first study in the identity literature that examines the effects of the 'levels' of identity (none to classification to real) on human behavior. We add to the conflict literature by including identity in a controlled setting. These results also add to the existing literature on the competitiveness of females (Apesteguia et al., 2012; Cadsby et al., 2013; Niederle and Vesterlund, 2007, 2011), that has thus far shown mixed results.

The results, however, leave some open issues. First, as mentioned, the results cannot tease out the effects of identity on in-group love versus out-group hate and we conclude that a real identity has a direct effect on parochial altruism. ${ }^{11}$ Second, we have implemented a specific definition of classification as introduced by Sen (2007). However, he also mentions that when a classification "acquires derivative relevance", then it might have similar effect as an identity. Borrowing an example from Sen (2007), the time of birth is only a classification. But if some dictator decides to kill all people born on a particular time of the day, then a salience of that classification will acquire serious relevance and will have similar effects as identity. Our experiment is not designed to capture this concept. Third, it is not possible to certainly extrapolate and generalize the results to all races beyond the two involved in this experiment. Specifically, the quantitative results might change due to norms and cultures if different races are considered and it is an empirical question as to whether the results generalize. Finally, as discussed earlier, the specific laboratory experiment boils down to situations in which the conflict is non-physical. As a result, the external validation of the results will have to be in the correct context.

Quite a few of the caveats stated above can be implemented in future research. But many other interesting extensions are also possible. The results seem to be specifically

\footnotetext{
${ }^{11}$ We tested whether individual efforts in the real identity treatment ever go beyond the level such that, if their own group wins, they will earn exactly the same as if they don't contribute at all. This would suggest that beating the other group has an intrinsic value beyond within-group efficiency. There are only 28 out of 216 individuals who exert effort more than that level at least in one round and the number is only 8 if we consider those who did so in 3 or more rounds.
} 
interesting since there is no pre-existing conflict between Whites and East Asians in the UK. But it will also be intriguing to see the effects when the same experiment is run between groups that have pre-existing conflicts. A lab-in-the-field experiment will help in such a case. Another extension would be to explore if different dimensions of identity have different effects on behavior. For example, it would be interesting to see if the results stated above can be generalized to other races or languages or political affiliation and whether Hypothesis 3 (symmetric effect across races) can then be rejected. Since we found gender effects, an obvious extension could be to replicate our experiment with controlled gender ratio. It would be useful to run an individual contest experiment that does not have the issues of in-group cooperation or free-riding. Finally, identifying mechanisms through which conflict intensity can be reduced will be a further important extension. 


\section{References}

Abbink, K., Brandts, J., Herrmann, B., \& Orzen, H. (2010). Intergroup conflict and intra-group punishment in an experimental contest game. The American Economic Review, 420-447.

Abbink, K., Brandts, J., Herrmann, B., \& Orzen, H. (2012). Parochial altruism in inter-group conflicts. Economics Letters, 117(1), 45-48.

Akerlof, G.A., \& Kranton, R.E. (2000). Economics and Identity, Quarterly Journal of Economics, 115(3), 715-753.

Akerlof, G.A., \& Kranton, R.E. (2002). Identity and schooling: Some lessons for the economics of education. Journal of economic literature, 40(4), 1167-1201.

Akerlof, G.A., \& Kranton, R.E. (2005). Identity and the Economics of Organizations. The Journal of Economic Perspectives, 19(1), 9-32.

Akerlof, G.A., \& Kranton, R.E. (2008). Identity, supervision, and work groups. The American Economic Review, 98(2), 212-217.

Akerlof, G.A., \& Kranton, R.E. (2010). Identity economics: How our identities shape our work, wages, and well-being. Princeton University Press.

Apesteguia, J., Azmat, G., \& Iriberri, N. (2012). The impact of gender composition on team performance and decision making: Evidence from the field. Management Science, 58(1), 78-93.

Baik, K.H., Chowdhury, S.M., \& Ramalingam, A. (2016). The Effects of Conflict Budget on the Intensity of Conflict: An Experimental Investigation. UEA Working paper.

Basu, K. (2005). Racial conflict and the malignancy of identity. The Journal of Economic Inequality, 3(3), 221-241.

Benjamin, D. J., Choi, J. J., \& Fisher, G.W. (2010). Religious identity and economic behavior (No. w15925). National Bureau of Economic Research.

Brewer, M. B. (1999). The psychology of prejudice: Ingroup love or outgroup hate?. Journal of social issues, $55,429-444$.

Brewer, M. B., \& Kramer, R. M. (1986). Choice behavior in social dilemmas: Effects of social identity, group size, and decision framing. Journal of personality and social psychology, 50(3), 543.

Cason, T. N., Sheremeta, R. M., \& Zhang, J. (2012). Communication and efficiency in competitive coordination games. Games and Economic Behavior, 76(1), 26-43.

Cadsby, C. B., Servátka, M., \& Song, F. (2013). How Competitive are Female Professionals? A Tale of Identity Conflict. Journal of Economic Behavior \& Organization. 
Casari, M., Ham, J.C., \& Kagel, J.H. (2007). Selection Bias, Demographic Effects, and Ability Effects in Common Value Auction Experiments. American Economic Review, 97(4): 1278-1304.

Chen, R.W., \& Chen, Y. (2011). The potential of social identity for equilibrium selection. American Economic Review, 101, 2562-2589.

Chen, Y., \& Li, S.X. (2009). Group identity and social preferences. American Economic Review 99, 431-457.

Chen, Y., Li, S. X., Liu, T. X., \& Shih, M. (2014). Which hat to wear? Impact of natural identities on coordination and cooperation. Games and Economic Behavior, 84, 58-86.

Chowdhury, S. M., Lee, D., \& Sheremeta, R. M. (2013). Top guns may not fire: Best-shot group contests with group-specific public good prizes. Journal of Economic Behavior \& Organization, 92, 94-103.

Chowdhury, S. M., \& Topolyan, I. (2016). The Attack-And-Defense Group Contests: Best Shot Versus Weakest Link. Economic Inquiry, 54(1), 548-557.

Choi, J.K., \& Bowles, S. (2007). The Coevolution of Parochial Altruism and War, Science, 318, 636-640.

Croson, R., \& Gneezy, U. (2009). Gender differences in preferences. Journal of Economic Literature 47, 448-474.

Croson, R., Marks, M., \& Snyder, J. (2008). Groups work for women: Gender and group identity in social dilemmas. Negotiation Journal, 24(4), 411-427.

Dechenaux, E., Kovenock, D., \& Sheremeta, R. M. (2015). A survey of experimental research on contests, all-pay auctions and tournaments. Experimental Economics, 609-669.

Deck, C., Farmer, A., \& Zeng, D.Z. (2009). Arbitration and Bargaining across the Pacific. Southern Economic Journal, 76(1), 183-197.

Drouvelis, M., \& Nosenzo, D. (2013). Group identity and leading-by-example. Journal of Economic Psychology, 39, 414-425.

Eckel, C.C., \& Grossman, P.J. (2005). Managing diversity by creating team identity, Journal of Economic Behavior and Organization, 58, 371-392.

Eckel, C.C., \& Grossman, P.J. (2008). Differences in the Economic Decisions of Men and Women: Experimental Evidence, in C.R. Plott and V.L. Smith (eds.) Handbook of Experimental Economics Results, North-Holland, Oxford, 509-519.

Esteban, J., Mayoral, L., \& Ray, D. (2012a). Ethnicity and conflict: An empirical study. The American Economic Review, 102(4), 1310-1342. 
Esteban, J., Mayoral, L., \& Ray, D. (2012b). Ethnicity and Conflict: Theory and Facts, Science, $336,858-865$.

Fershtman, C., \& Gneezy, U. (2001). Discrimination in a segmented society: An experimental approach. The Quarterly Journal of Economics, 116(1), 351-377.

Fischbacher, U. (2007). z-Tree: Zurich toolbox for ready-made economic experiments, Experimental Economics, 10 (2), 171-178.

Goette, L., Huffman, D., \& Meier, S. (2006). The impact of group membership on cooperation and norm enforcement: Evidence using random assignment to real social groups. The American economic review, 96(2), 212-216.

Greiner, B. (2015). Subject pool recruitment procedures: organizing experiments with ORSEE. Journal of the Economic Science Association, 1(1), 114-125.

Gumen, A. (2015). Intergroup Conflict and the Provision of Public Goods: An Experiment. Mimeo.

Halevy, N., Bornstein, G., \& Sagiv, L. (2008). "In-Group Love" and "Out-Group Hate" as Motives for Individual Participation in Intergroup Conflict A New Game Paradigm. Psychological Science, 19(4), 405-411.

Hargreaves-Heap, S. P., \& Zizzo, D. J. (2009). The value of groups. The American Economic Review, 295-323.

Katz, E., Nitzan, S., \& Rosenberg, J. (1990). Rent seeking for pure public goods. Public Choice, $65,49-60$.

Kelly, R. C. (2005). The evolution of lethal intergroup violence. Proceedings of the National Academy of Sciences of the United States of America, 102(43), 15294-15298.

Klor, E. F., \& Shayo, M. (2010). Social identity and preferences over redistribution. Journal of Public Economics, 94(3), 269-278.

Kranton, R., Pease, M., Sanders, S., \& Huettel, S. (2012). Identity, Group Conflict, and Social Preferences. Working paper

Lee, D. (2012). Weakest-link contests with group-specific public good prizes. European Journal of Political Economy, 28(2), 238-248.

Morita, H., \& Servátka, M. (2013). Group identity and relation-specific investment: An experimental investigation. European Economic Review, 58, 95-109.

Niederle, M., \& Vesterlund, L. (2007). Do Women Shy Away from Competition? Do Men Compete Too Much?, Quarterly Journal of Economics, 122, 1067-1101.

Niederle, M., \& Vesterlund, L. (2011). Gender and Competition, Annual Review of Economics, 3, 601-630. 
Price, C. R., \& Sheremeta, R. M. (2015). Endowment origin, demographic effects and individual preferences in contests. Journal of Economics and Management Strategy, 24, 597-619.

Reynal-Querol, M. (2002). Ethnicity, political systems, and civil wars. Journal of Conflict Resolution, 46(1), 29-54.

Robinson, J. A. (2001). Social identity, inequality and conflict. Economics of Governance, 2(1), 85-99.

Sassenberg, K., Kessler, T., \& Mummendey, A. (2003). Less negative= more positive? Social discrimination as avoidance or approach. Journal of Experimental Social Psychology, 39(1), 48-58.

Sen, A. (1985). Goals, commitment, and identity. Journal of Law Economics \& Organization, $1,341$.

Sen, A. (2007). Identity and violence: The illusion of destiny. Penguin Books India.

Sherif, M., Harvey, O. J., White, B. J., Hood, W. R., \& Sherif, C. W. (1961). Intergroup conflict and cooperation: The Robbers Cave experiment (Vol. 10). Norman, OK: University Book Exchange.

Shih, M., Pittinsky, T.L., \& Ambady, N. (1999). Stereotype Susceptibility: Identity Salience and Shifts in Quantitative Performance, Psychological Science, 10 (1), 81-84.

Solow, J. L., \& Kirkwood, N. (2002). Group identity and gender in public goods experiments. Journal of Economic Behavior \& Organization, 48(4), 403-412.

Steele, C. M., Spencer, S. J., \& Aronson, J. (2002). Contending with group image: The psychology of stereotype and social identity threat. Advances in experimental social psychology, 34, 379-440.

Stoddard, O., \& Leibbrandt, A. (2014). An Experimental Study On The Relevance And Scope Of Nationality As A Coordination Device. Economic Inquiry, 52(4), 1392-1407.

Tajfel, H., \& Turner, J. C. (1979). An integrative theory of intergroup conflict. The social psychology of intergroup relations, 33, 47.

Tajfel, H. (2010). Social identity and intergroup relations. Cambridge University Press.

Turner, J. (1978). Social Categorization and Social Discrimination in the Minimal Group Paradigm, in Henri Tajfel, ed., Differentiation between Social Groups, Academic Press.

Tullock, G. (1980). Efficient Rent Seeking. In James M. Buchanan, Robert D. Tollison, Gordon Tullock, (Eds.), Toward a theory of the rent-seeking society. College Station, TX: Texas A\&M University Press, 97-112. 
Weisel, O., \& Böhm, R. (2015). "Ingroup love" and "outgroup hate" in intergroup conflict between natural groups. Journal of Experimental Social Psychology, 60, 110-120.

Weisel, O., \& Zultan, R. I. (2016). Social motives in intergroup conflict. European Economic Review, Forthcoming.

Young, C. (1982). Patterns of social conflict: State, class, and ethnicity. Daedalus, 111(2), 7198. 


\section{Appendix I: Tables}

Table A1. Hurdle model of effort level contingent upon no free-ride

\begin{tabular}{|c|c|}
\hline \multicolumn{2}{|c|}{$1^{\text {st }}$ stage : Random Effect Probit model } \\
\hline Dependent variable: \# & Free-ride \\
\hline Color & $\begin{array}{c}0.095 \\
(0.229)\end{array}$ \\
\hline Race & $\begin{array}{l}0.402^{*} \\
(0.225)\end{array}$ \\
\hline E. Asian & $\begin{array}{c}0.053 \\
(0.140)\end{array}$ \\
\hline Female & $\begin{array}{l}0.361^{*} \\
(0.192)\end{array}$ \\
\hline Constant & $\begin{array}{c}0.825^{* * *} \\
(0.185)\end{array}$ \\
\hline \# of Obs. & 4,320 \\
\hline \# of subjects & 216 \\
\hline $2^{\text {nd }}$ stage : Random I & Tobit model \\
\hline Dependent variable: & Effort $_{i, t}$ \\
\hline Color & $\begin{array}{c}0.919 \\
(0.983)\end{array}$ \\
\hline Race & $\begin{array}{l}1.601^{*} \\
(0.969)\end{array}$ \\
\hline Lag rival effort & $\begin{array}{c}0.060 * * * \\
(0.008)\end{array}$ \\
\hline Lag own effort & $\begin{array}{c}0.267 * * * \\
(0.017)\end{array}$ \\
\hline Period & $\begin{array}{c}-0.258 * * * \\
(0.030)\end{array}$ \\
\hline E. Asian & $\begin{array}{c}0.614 \\
(0.803)\end{array}$ \\
\hline Female & $\begin{array}{c}0.827 \\
(0.804)\end{array}$ \\
\hline Constant & $\begin{array}{c}11.061 * * * \\
(1.056)\end{array}$ \\
\hline $\begin{array}{l}\text { \# of Obs. } \\
\text { \# of subjects }\end{array}$ & $\begin{array}{l}3,165 \\
207\end{array}$ \\
\hline
\end{tabular}

$* * *, * *$, and $*$ respectively indicate significance at the $1 \%, 5 \%$ and $10 \%$ level. Figures in parentheses are robust standard errors. 
Table A2. Determinants of individual efforts

\begin{tabular}{ccccc}
\hline $\begin{array}{c}\text { Dep variable: } \\
\text { Effort }{ }_{\mathrm{i}, \mathrm{t}}\end{array}$ & All & $\begin{array}{c}\text { Baseline }+ \\
\text { Color }\end{array}$ & $\begin{array}{c}\text { Baseline }+ \\
\text { Race }\end{array}$ & $\begin{array}{c}\text { Color }+ \\
\text { Race }\end{array}$ \\
\hline Color & 0.321 & 0.343 & & \\
Race & $(0.473)$ & $(0.548)$ & $1.030^{* *}$ & 0.813 \\
& $1.156^{* *}$ & & $(0.508)$ & $(0.517)$ \\
Lag rival effort & $(0.569)$ & & & \\
& $0.056^{* *}$ & $0.042^{*}$ & $0.082^{* * *}$ & $0.046^{* * *}$ \\
Lag own effort & $(0.016)$ & $(0.024)$ & $(0.012)$ & $(0.018)$ \\
& $0.547^{* * *}$ & $0.546^{* * *}$ & $0.502^{* * *}$ & $0.579^{* * *}$ \\
Period & $(0.040)$ & $(0.046)$ & $(0.047)$ & $(0.047)$ \\
& $-0.128^{* * *}$ & $-0.124^{* * *}$ & $-0.128^{* * *}$ & $-0.135^{* * *}$ \\
& $(0.027)$ & $(0.039)$ & $(0.027)$ & $(0.033)$ \\
E. Asian & & & & 0.657 \\
Female & 0.485 & 0.454 & 0.325 & $(0.637)$ \\
& $(0.476)$ & $(0.581)$ & $(0.508)$ & $1.558^{* * *}$ \\
Constant & $0.998^{* *}$ & 0.450 & $0.879^{*}$ & $(0.553)$ \\
& $(0.468)$ & $(0.605)$ & $(0.532)$ & $3.415^{* * *}$ \\
\# of Obs. & $3.397^{* * *}$ & $4.176^{* * *}$ & $3.143^{* * *}$ & $(0.962)$ \\
\hline \# of subjects & $(0.759)$ & $(0.791)$ & $(0.823)$ & 2,736 \\
\hline & 4,104 & 2,736 & 2,736 & 144 \\
\hline
\end{tabular}

$* * *, * *$, and $*$ respectively indicate significance at the $1 \%, 5 \%$ and $10 \%$ level. Figures in parentheses are robust standard errors. 
Table A3. Effects of Gender

\begin{tabular}{|c|c|c|c|c|}
\hline $\begin{array}{l}\text { Dependent } \\
\text { variable: Effort }{ }_{i, t}\end{array}$ & All & $\begin{array}{c}\text { Baseline vs. } \\
\text { Color }\end{array}$ & $\begin{array}{c}\text { Baseline vs. } \\
\text { Race }\end{array}$ & Color vs. Race \\
\hline Baselinexfemale & $\begin{array}{l}-0.440 \\
(0.485)\end{array}$ & $\begin{array}{l}-0.371 \\
(0.499)\end{array}$ & $\begin{array}{l}-0.491 \\
(0.554)\end{array}$ & \\
\hline Color $\times$ male & $\begin{array}{l}-0.559 \\
(0.693)\end{array}$ & $\begin{array}{l}-0.480 \\
(0.721)\end{array}$ & & \\
\hline Color $\times$ female & $\begin{array}{r}0.745 \\
(0.816)\end{array}$ & $\begin{array}{r}0.813 \\
(0.844)\end{array}$ & & $\begin{array}{c}1.121 \\
(0.975)\end{array}$ \\
\hline Racexmale & $\begin{array}{l}-0.140 \\
(0.710)\end{array}$ & & $\begin{array}{l}-0.343 \\
(0.711)\end{array}$ & $\begin{array}{r}0.400 \\
(0.762)\end{array}$ \\
\hline Racexfemale & $\begin{array}{l}1.995^{* *} \\
(0.803)\end{array}$ & & $\begin{array}{l}1.921^{* *} \\
(0.769)\end{array}$ & $\begin{array}{l}2.389^{* * * *} \\
(0.743)\end{array}$ \\
\hline Lag rival effort & $\begin{array}{l}0.057^{* * * *} \\
(0.016)\end{array}$ & $\begin{array}{c}0.044^{*} \\
(0.024)\end{array}$ & $\begin{array}{l}0.083^{* * *} \\
(0.012)\end{array}$ & $\begin{array}{l}0.046^{* * *} \\
(0.018)\end{array}$ \\
\hline Lag own effort & $\begin{array}{l}0.543^{* * * *} \\
(0.038)\end{array}$ & $\begin{array}{l}0.544^{* * *} \\
(0.045)\end{array}$ & $\begin{array}{l}0.495^{* * *} \\
(0.043)\end{array}$ & $\begin{array}{l}0.578^{* * *} \\
(0.047)\end{array}$ \\
\hline Period & $\begin{array}{c}-0.130^{* * * *} \\
(0.027)\end{array}$ & $\begin{array}{c}-0.123^{* * * *} \\
(0.039)\end{array}$ & $\begin{array}{c}-0.132^{\text {**** }} \\
(0.027)\end{array}$ & $\begin{array}{c}-0.137^{* * *} \\
(0.033)\end{array}$ \\
\hline E. Asian & $\begin{array}{r}0.556 \\
(0.508)\end{array}$ & $\begin{array}{r}0.426 \\
(0.605)\end{array}$ & $\begin{array}{r}0.463 \\
(0.566)\end{array}$ & $\begin{array}{r}0.716 \\
(0.655)\end{array}$ \\
\hline Constant & $\begin{array}{l}4.156^{* * *} \\
(0.664)\end{array}$ & $\begin{array}{l}4.557^{* * *} \\
(0.806)\end{array}$ & $\begin{array}{l}3.893^{* * *} \\
(0.653)\end{array}$ & $\begin{array}{l}3.653^{* * *} \\
(0.887)\end{array}$ \\
\hline$N$ & 4,104 & 2,736 & 2,736 & 2,736 \\
\hline
\end{tabular}

$* * *, * *$, and $*$ respectively indicate significance at the $1 \%, 5 \%$ and $10 \%$ level. Figures in parentheses are robust standard errors. 
Table A4. Random effects regression with interactions

\begin{tabular}{|c|c|}
\hline Dependent variable: & Effort $_{i, t}$ \\
\hline Baseline* Lag rival effort & $\begin{array}{c}0.082^{* * *} \\
(0.021)\end{array}$ \\
\hline Color* Lag rival effort & $\begin{array}{l}0.0240 \\
(0.025)\end{array}$ \\
\hline Race* $^{*}$ Lag rival effort & $\begin{array}{c}0.0731^{* * *} \\
(0.015)\end{array}$ \\
\hline Baseline* Lag own effort & $\begin{array}{c}0.440^{* * *} \\
(0.051)\end{array}$ \\
\hline Color* Lag own effort & $\begin{array}{c}0.618^{* * *} \\
(0.059)\end{array}$ \\
\hline Race* Lag own effort & $\begin{array}{c}0.545^{* * *} \\
(0.065)\end{array}$ \\
\hline Period & $\begin{array}{c}-0.128^{* * *} \\
(0.027)\end{array}$ \\
\hline E. Asian & $\begin{array}{c}0.409 \\
(0.424)\end{array}$ \\
\hline Female & $\begin{array}{l}0.855^{* *} \\
(0.426)\end{array}$ \\
\hline Constant & $\begin{array}{l}3.987^{* * *} \\
(0.642)\end{array}$ \\
\hline Observations & 4104 \\
\hline
\end{tabular}

$* * *, * *$, and $*$ respectively indicate significance at the $1 \%, 5 \%$ and $10 \%$ level. Figures in parentheses are robust standard errors. 


\section{Appendix II: Instructions}

\section{Instructions for the Baseline Treatment}

\section{GENERAL INSTRUCTIONS}

This is an experiment in the economics of decision making. The instructions are simple. If you follow them closely and make appropriate decisions, you can earn an appreciable amount of money.

Experimental Currency is used in the experiment and your decisions and earnings will be recorded in Experimental Currency Units (ECUs). At the end of today's experiment, you will be paid in private and in cash. ECUs will be converted to Pound Sterling at a rate of _25_ECUs to _1_ British Pound.

It is extremely important that you remain silent and do not look at other people's work. If you have any questions, or need assistance of any kind, please raise your hand and an experimenter will come to you. If you talk, laugh, exclaim out loud, etc., you will be asked to leave and you will not be paid. We expect and appreciate your cooperation.

\section{EXPERIMENTAL INSTRUCTIONS}

\section{YOUR DECISION}

The experiment consists of $\mathbf{2 0}$ decision-making periods. At the beginning of the experiment, you will be anonymously placed into a group of $\mathbf{3}$ people. Your group will then be anonymously matched with another group of 3 people. In each period your group as well as the group your group is matched with will remain the same. However, at no point will you know who your group members are or who the members of the other group are. Also, you will not know any information about the members of your group or the members of the other group.

Each period you will be given an initial endowment of $\mathbf{6 0}$ ECUs. You will then decide how much to allocate to a group account or an individual account. On your screen, you will be asked to enter your allocation to the group account. You may allocate any integer number of 
ECUs between, and including, $\mathbf{0}$ and $\mathbf{6 0}$. Any ECUs you do not allocate to the group account will automatically be allocated to your individual account. An example of your decision screen is shown below.

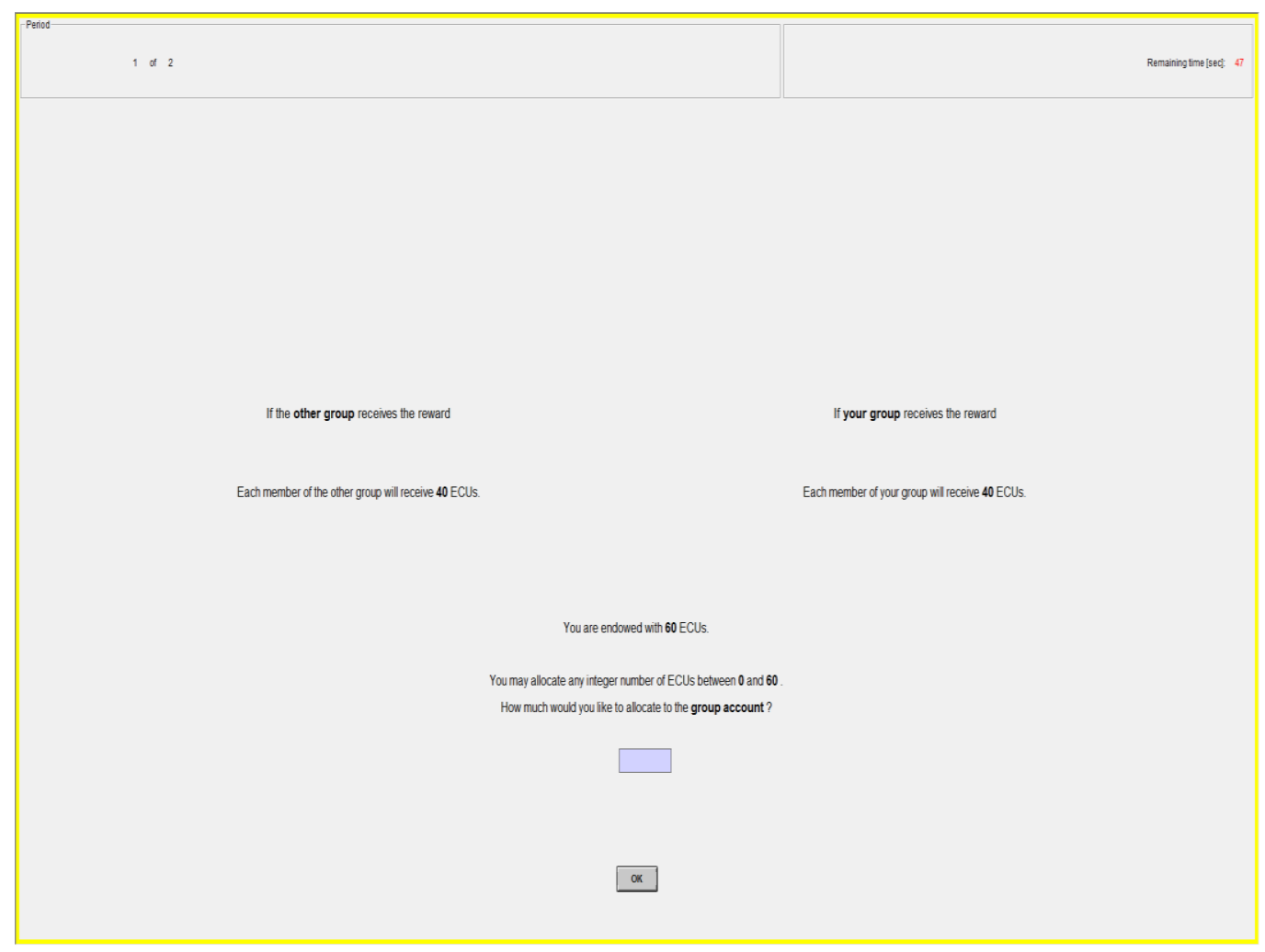

At the end of $\boldsymbol{e a c h}$ period, either your group or the other group will receive a reward of $\mathbf{1 2 0}$ ECUs (40 ECUs per group member). In each period, only one of the two groups can obtain the reward. By contributing to your group account you increase the chance of receiving the reward for your group. If the total number of ECUs in your group account exceeds the total number of ECUs in the other group's account, your group has a higher chance of receiving the reward.

The computer will assign the reward either to your group or to the other group, via a random draw that depends on the total allocation in the group accounts by the two groups. Below is a hypothetical example used to illustrate how the computer makes a random draw to decide which group wins the reward.

Note: The following example is for illustrative purposes only.

\section{Example 1. Random Draw}

Think of the random draw in the following way. For each ECUs in your group's account the computer puts 1 red token into a box and for each ECU in the other group's account the 
computer puts 1 black token. Then the computer randomly draws one token out of the box. If the drawn token is red then your group receives the reward, if the drawn token is black then the other group receives the reward. Suppose that members of both groups have allocated their ECUs in the following way (as shown in Table 1 below).

Table 1 - Allocation of ECUs by members of both groups

\begin{tabular}{|l|c|c|c|}
\hline $\begin{array}{c}\text { Your } \\
\text { Group }\end{array}$ & $\begin{array}{c}\text { Endow- } \\
\text { ment } \\
\text { (ECUs) }\end{array}$ & $\begin{array}{c}\text { Allocation } \\
\text { to the } \\
\text { individual } \\
\text { account }\end{array}$ & $\begin{array}{c}\text { Allocation } \\
\text { to the } \\
\text { group } \\
\text { account }\end{array}$ \\
\hline Person 1 & 60 & 40 & $\mathbf{2 0}$ \\
Person 2 & 60 & 45 & $\mathbf{1 5}$ \\
Total & 60 & 50 & $\mathbf{1 0}$ \\
\hline
\end{tabular}

\begin{tabular}{|l|c|c|c|}
\hline $\begin{array}{c}\text { Other } \\
\text { Group }\end{array}$ & $\begin{array}{c}\text { Endow- } \\
\text { ment } \\
\text { (ECUs) }\end{array}$ & $\begin{array}{c}\text { Allocation } \\
\text { to the } \\
\text { individual } \\
\text { account }\end{array}$ & $\begin{array}{c}\text { Allocation } \\
\text { to the } \\
\text { group } \\
\text { account }\end{array}$ \\
\hline Person 1 & 60 & 50 & $\mathbf{1 0}$ \\
Person 2 & 60 & 60 & $\mathbf{0}$ \\
\hline Total & 180 & 165 & $\mathbf{5}$ \\
\hline
\end{tabular}

Members of your group have allocated a total of 45 ECUs to your group account while members of the other group have allocated 15 ECUs. Thus, the computer will place $\mathbf{4 5}$ red tokens and 15 black tokens into the box ( 60 tokens total). Then the computer will randomly draw one token out of the box. You can see that since your group has contributed more it has a higher chance of receiving the reward - your group will receive the reward 45 out of 60 times. The other group has a lower chance of receiving the reward - $\mathbf{1 5}$ out of $\mathbf{6 0}$ times.

A group can never guarantee itself the reward. However, by increasing your contribution, you can increase your group's chance of receiving the reward. If your group receives the reward, 120 ECUs will be divided equally among the members of your group, i.e., you and the other 2 members of your group will receive 40 ECUs each. 


\section{YOUR EARNINGS}

\section{EARNINGS IN EACH PERIOD:}

After all participants have made their decisions, your earnings for the period are calculated.

1) For each ECU in your individual account, you will earn $\mathbf{1}$ ECU in return. So, if you keep all 60 ECUs that you are endowed with in your individual account you will earn 60 ECUs.

2) You can also earn some ECUs from your group account. After all contributions are made, the computer uses the random draw process described above to decide which group wins the reward. If your group wins the reward, you will earn $\mathbf{4 0}$ ECUs from your group account in addition to your earnings from your individual account. Each of the other 2 members of your group will also earn 40 ECUs from the group account. If the other group wins the reward, you and the other 2 members of your group receive nothing from your group account. In this event, your period earnings will be equal to your earnings from your individual account.

Your period earnings are the sum of the earnings from your individual account and the earnings from your group account. The following example illustrates the calculation of period earnings.

Note: The following example is for illustrative purposes only.

\section{Example 2. Period Earnings}

In Example 1, your group allocated a total of 45 ECUs while other group allocated a total of 15 ECUs to the group accounts. Let's say the computer made a random draw and your group received the reward. Thus, all the members of your group receive 40 ECUs each from your group account plus earnings from their individual accounts. All members of the other group receive earnings only from their individual accounts, since their group did not receive the reward. The calculation of the total earnings is shown in Table 2 below. 
Table 2 - Calculation of earnings for both groups

\begin{tabular}{|l|c|c|c|}
\hline $\begin{array}{c}\text { Your } \\
\text { group }\end{array}$ & $\begin{array}{c}\text { Earnings } \\
\text { from } \\
\text { group } \\
\text { account }\end{array}$ & $\begin{array}{c}\text { Earnings } \\
\text { from } \\
\text { individual } \\
\text { account }\end{array}$ & $\begin{array}{c}\text { Total period } \\
\text { earnings }\end{array}$ \\
\hline Person 1 & $\mathbf{4 0}$ & $\mathbf{4 0}$ & $40+40=\mathbf{8 0}$ \\
Person 2 & $\mathbf{4 0}$ & $\mathbf{4 5}$ & $40+45=\mathbf{8 5}$ \\
Person 3 & $\mathbf{4 0}$ & $\mathbf{5 0}$ & $40+50=\mathbf{9 0}$ \\
\hline Total & $\mathbf{1 2 0}$ & $\mathbf{1 3 5}$ & 255 \\
\hline
\end{tabular}

\begin{tabular}{|l|c|c|c|}
\hline $\begin{array}{c}\text { Other } \\
\text { group }\end{array}$ & $\begin{array}{c}\text { Earnings } \\
\text { from } \\
\text { group } \\
\text { account }\end{array}$ & $\begin{array}{c}\text { Earnings } \\
\text { from } \\
\text { individual } \\
\text { account }\end{array}$ & $\begin{array}{c}\text { Total } \\
\text { period } \\
\text { earnings }\end{array}$ \\
\hline Person 1 & $\mathbf{0}$ & $\mathbf{5 0}$ & $\mathbf{5 0}$ \\
Person 2 & $\mathbf{0}$ & $\mathbf{6 0}$ & $\mathbf{6 0}$ \\
Person 3 & $\mathbf{0}$ & $\mathbf{5 5}$ & $\mathbf{5 5}$ \\
\hline Total & $\mathbf{0}$ & $\mathbf{1 6 5}$ & 165 \\
\hline
\end{tabular}

\section{EARNINGS FROM THE EXPERIMENT:}

At the end of the experiment we will randomly choose $\mathbf{5}$ of the 20 periods for actual payment using a computer program. You will be paid the sum of the earnings in each of these 5 periods. These earnings will be converted to cash at the exchange rate mentioned earlier and will be paid at the end of the experiment.

Note: All participants in this session will be paid for the same 5 periods.

\section{OUTCOME SCREEN}

At the end of each period, the total number of ECUs in the two groups' accounts, which group received the reward, your earnings from your individual and your group accounts, and your total earnings for the period are reported on the outcome screen as shown below. Please record your results for the period on your record sheet under the appropriate heading. 


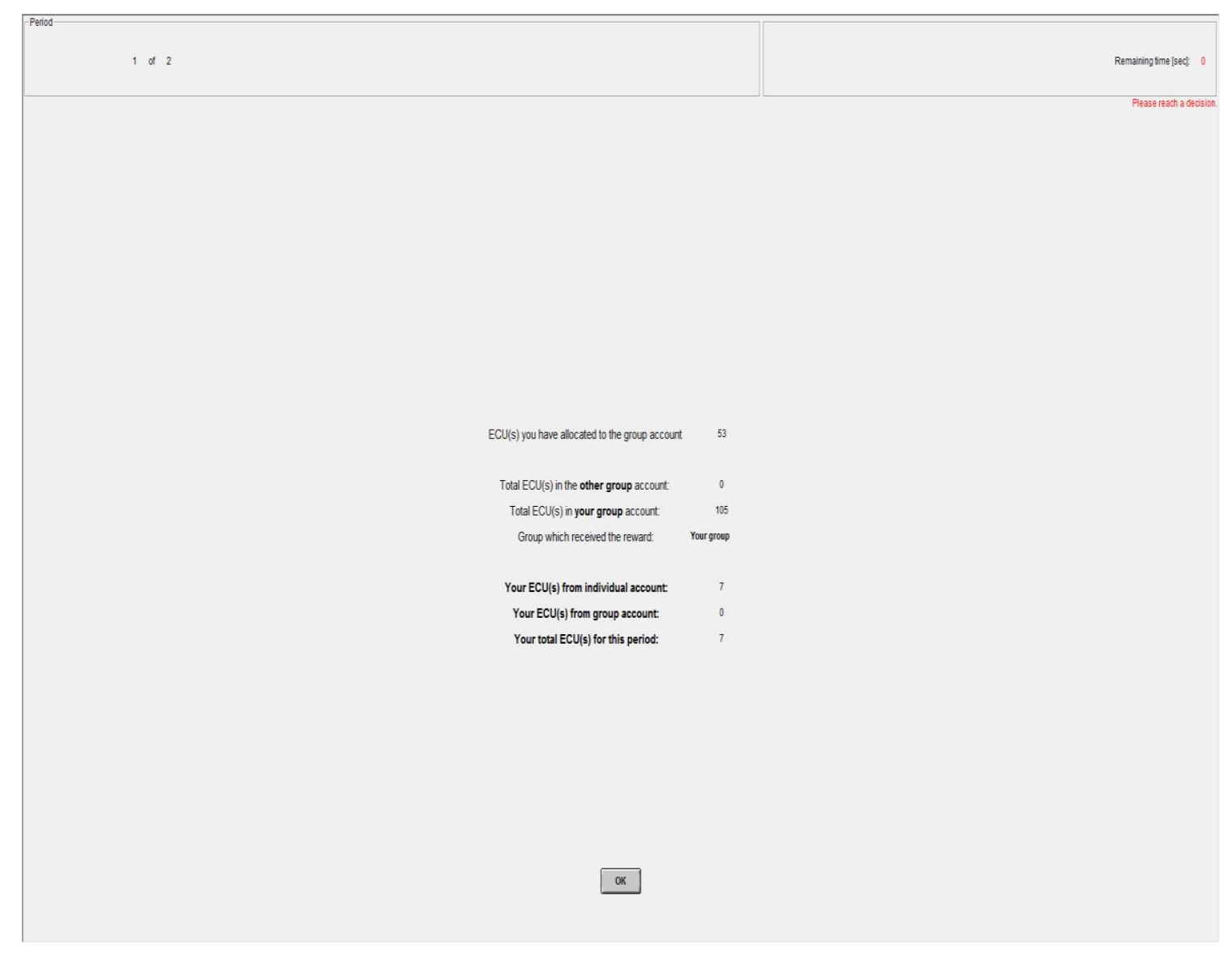

\section{QUESTIONS TO HELP YOU BETTER UNDERSTAND THE DECISION TASKS}

When everyone has finished reading the instructions, and before the experiment begins, we will ask you a few questions regarding the decisions you will make in the experiment. The questions will help you understand the calculation of your earnings and ensure that you have understood the instructions. 
Personal Record Sheet

\begin{tabular}{|c|c|c|c|}
\hline Period & $\begin{array}{l}\text { Earnings from } \\
\text { individual account }\end{array}$ & $\begin{array}{l}\text { Earnings from } \\
\text { your group } \\
\text { account }\end{array}$ & $\begin{array}{l}\text { Total earnings } \\
\text { for this period }\end{array}$ \\
\hline 1 & & & \\
\hline 2 & & & \\
\hline 3 & & & \\
\hline 4 & & & \\
\hline 5 & & & \\
\hline 6 & & & \\
\hline 7 & & & \\
\hline 8 & & & \\
\hline 9 & & & \\
\hline 10 & & & \\
\hline 11 & & & \\
\hline 12 & & & \\
\hline 13 & & & \\
\hline 14 & & & \\
\hline 15 & & & \\
\hline 16 & & & \\
\hline 17 & & & \\
\hline 18 & & & \\
\hline 19 & & & \\
\hline 20 & & & \\
\hline
\end{tabular}


Total Earnings

\begin{tabular}{|l|l|}
\hline Period Chosen & Total earnings for this period \\
\hline & \\
\hline & \\
\hline & \\
\hline & \\
\hline Total & $=$ \\
\hline
\end{tabular}

Sum earnings from table above:

Divide earnings by conversion rate:

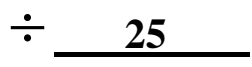

Earnings in British Pounds:

$£$

Earnings from Showing up:

$£ 2$ (2)

Total payment received: (1)+(2)

$£$ 


\section{QUIZ}

1. Does group composition change across periods in the experiment?

Ans. Yes No

\section{Questions 2 to 6 apply to the following information.}

In a given period, suppose the members of your group and the other group chose to allocate their ECUs to the group account as it is shown in the table below.

\begin{tabular}{|l|c|c|c|}
\hline $\begin{array}{c}\text { Your } \\
\text { group }\end{array}$ & $\begin{array}{c}\text { Endow- } \\
\text { ment }\end{array}$ & $\begin{array}{c}\text { Allocation } \\
\text { to the } \\
\text { individual } \\
\text { account }\end{array}$ & $\begin{array}{c}\text { Allocation } \\
\text { to the } \\
\text { group } \\
\text { account }\end{array}$ \\
\hline Person 1 & 60 & 35 & 25 \\
Person 2 & 60 & 60 & 0 \\
\hline Person 3 & 60 & 55 & 5 \\
\hline Total & 180 & 150 & 30 \\
\hline
\end{tabular}

\begin{tabular}{|l|c|c|c|}
\hline $\begin{array}{c}\text { Other } \\
\text { group }\end{array}$ & $\begin{array}{c}\text { Endow- } \\
\text { ment }\end{array}$ & $\begin{array}{c}\text { Allocation } \\
\text { to the } \\
\text { individual } \\
\text { account }\end{array}$ & $\begin{array}{c}\text { Allocation } \\
\text { to the } \\
\text { group } \\
\text { account }\end{array}$ \\
\hline Person 1 & 60 & 40 & 20 \\
Person 2 & 60 & 40 & 20 \\
Person 3 & 60 & 50 & 10 \\
\hline Total & 180 & 130 & 50 \\
\hline
\end{tabular}

2. How many total ECUs will the computer place into the box?

Ans.

3. If the computer makes a random draw out of the box what is the chance of your group receiving the reward?

Ans.

out of

4. If the computer makes a random draw out of the box what is the chance of the other group receiving the reward?

Ans. out of 
5. If you are Person 1 in your group and your group did not receive the reward what are your period earnings?

Ans.

6. If you are Person 2 in your group and your group received the reward what are your period earnings?

Ans.

\section{EXPLANATIONS FOR QUIZ ANSWERS}

1. Does group composition change across periods in the experiment? Correct answer: No

\section{Questions 2 to 6 apply to the following information.}

In a given period, suppose the members of your group and the other group chose to allocate their ECUs to the group account as it is shown in the table below.

\begin{tabular}{|l|c|c|c|}
\hline $\begin{array}{c}\text { Your } \\
\text { group }\end{array}$ & $\begin{array}{c}\text { Endow- } \\
\text { ment }\end{array}$ & $\begin{array}{c}\text { Allocation } \\
\text { to the } \\
\text { individual } \\
\text { account }\end{array}$ & $\begin{array}{c}\text { Allocation } \\
\text { to the } \\
\text { group } \\
\text { account }\end{array}$ \\
\hline Person 1 & 60 & 35 & 25 \\
Person 2 & 60 & 60 & 0 \\
Person 3 & 60 & 55 & 5 \\
\hline Total & 180 & 150 & 30 \\
\hline
\end{tabular}

\begin{tabular}{|l|c|c|c|}
\hline $\begin{array}{c}\text { Other } \\
\text { group }\end{array}$ & $\begin{array}{c}\text { Endow- } \\
\text { ment }\end{array}$ & $\begin{array}{c}\text { Allocation } \\
\text { to the } \\
\text { individual } \\
\text { account }\end{array}$ & $\begin{array}{c}\text { Allocation } \\
\text { to the } \\
\text { group } \\
\text { account }\end{array}$ \\
\hline Person 1 & 60 & 40 & 20 \\
Person 2 & 60 & 40 & 20 \\
Person 3 & 60 & 50 & 10 \\
\hline Total & 180 & 130 & 50 \\
\hline
\end{tabular}


2. How many total ECUs will the computer place into the box? Correct answer: 80 Allocation to the group account by your group and by the other group, i.e., 30 from your group PLUS 50 from the other group.

3. If the computer makes a random draw out of the box what is the chance of your group receiving the reward? - Correct answer: 30 out of 80

Out of a total of 80 tokens, 30 belong to your group. Thus the chance of your group winning any random draw of one token from the box is 30 tokens out of 80 .

4. If the computer makes a random draw out of the box what is the chance of the other group receiving the reward? - Correct answer: 50 out of 80

Out of a total of 80 tokens, 50 belong to the other group. Thus the chance of the other group winning any random draw of one token from the box is 50 tokens out of 80 .

5. If you are Person 1 in your group and your group did not receive the reward what are your period earnings? Correct answer: 35

Since your group did not win the reward, your earnings from the group account for this period are zero. So, your period earnings are equal to your earnings from your individual account. From the above table, this is equal to 35 ECUs, your allocation to your individual account.

6. If you are Person 2 in your group and your group received the reward what are your period earnings? Correct answer: 100

Since your group did win the reward, your earnings from the group account for this period are 40 ECUs (Your group wins 120 ECUs which are split equally among all 3 of you). So, your period earnings are equal to your earnings from your individual account plus 40 ECUs (your earnings from the group account). From the above table, your allocation to your individual account is 60 . Thus your total period earnings are $60+40=100$ ECUs. 


\section{Instructions for the Color Treatment}

\section{GENERAL INSTRUCTIONS}

This is an experiment in the economics of decision making. The instructions are simple. If you follow them closely and make appropriate decisions, you can earn an appreciable amount of money.

Experimental Currency is used in the experiment and your decisions and earnings will be recorded in Experimental Currency Units (ECUs). At the end of today's experiment, you will be paid in private and in cash. ECUs will be converted to Pound Sterling at a rate of _25_ECUs to ___ British Pound.

It is extremely important that you remain silent and do not look at other people's work. If you have any questions, or need assistance of any kind, please raise your hand and an experimenter will come to you. If you talk, laugh, exclaim out loud, etc., you will be asked to leave and you will not be paid. We expect and appreciate your cooperation.

\section{EXPERIMENTAL INSTRUCTIONS}

\section{YOUR DECISION}

The experiment consists of $\mathbf{2 0}$ decision-making periods. At the beginning of the experiment, you will be anonymously placed into a group of $\mathbf{3}$ people. You will be placed in either a 'Green' group or a 'Blue' group. Your group will then be anonymously matched with another group of 3 people. If you are placed into a Blue group, then your group will be matched with a Green group. If you are placed into a Green group, then your group will be matched with a Blue group. In each period your group as well as the group your group is matched with will remain the same. However, at no point will you know who your group members are or who the members of the other group are. Also, you will not know any information about the members of your group or the members of the other group.

Each period you will be given an initial endowment of $\mathbf{6 0}$ ECUs. You will then decide how much to allocate to a group account or an individual account. On your screen, you will be asked to enter your allocation to the group account. You may allocate any integer number of 
ECUs between, and including, $\mathbf{0}$ and $\mathbf{6 0}$. Any ECUs you do not allocate to the group account will automatically be allocated to your individual account. An example of your decision screen is shown below.

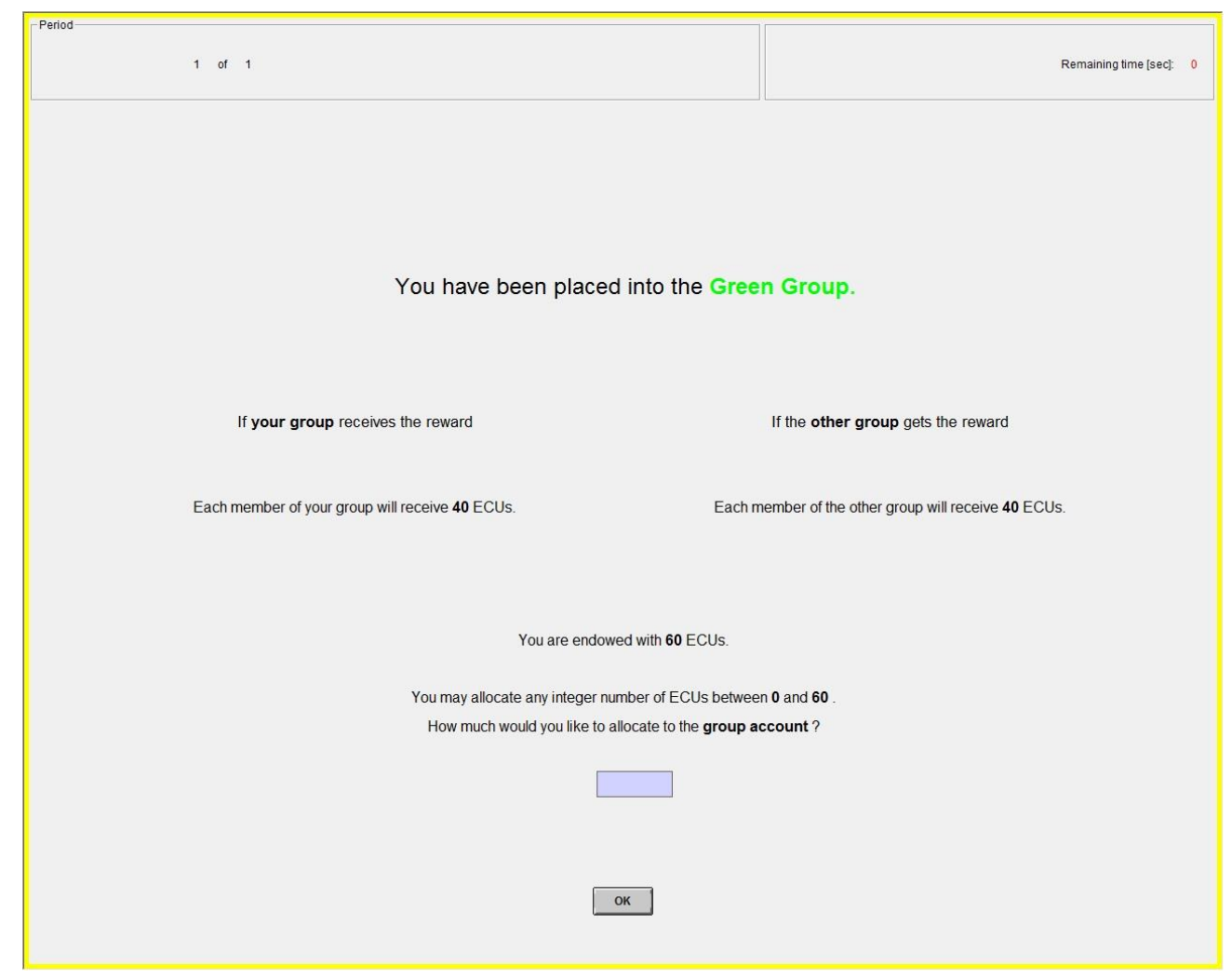

At the end of each period, either your group or the other group will receive a reward of $\mathbf{1 2 0}$ ECUs (40 ECUs per group member). In each period, only one of the two groups can obtain the reward. By contributing to your group account you increase the chance of receiving the reward for your group. If the total number of ECUs in your group account exceeds the total number of ECUs in the other group's account, your group has a higher chance of receiving the reward.

The computer will assign the reward either to your group or to the other group, via a random draw that depends on the total allocation in the group accounts by the two groups. Below is a hypothetical example used to illustrate how the computer makes a random draw to decide which group wins the reward.

Note: The following example is for illustrative purposes only.

\section{Example 1. Random Draw}

Think of the random draw in the following way. For each ECUs in your group's account the computer puts 1 red token into a box and for each ECU in the other group's account the 
computer puts 1 black token. Then the computer randomly draws one token out of the box. If the drawn token is red then your group receives the reward, if the drawn token is black then the other group receives the reward. Suppose that members of both groups have allocated their ECUs in the following way (as shown in Table 1 below).

Table 1 - Allocation of ECUs by members of both groups

\begin{tabular}{|l|c|c|c|}
\hline $\begin{array}{c}\text { Your } \\
\text { Group }\end{array}$ & $\begin{array}{c}\text { Endow- } \\
\text { ment } \\
\text { (ECUs) }\end{array}$ & $\begin{array}{c}\text { Allocation } \\
\text { to the } \\
\text { individual } \\
\text { account }\end{array}$ & $\begin{array}{c}\text { Allocation } \\
\text { to the } \\
\text { group } \\
\text { account }\end{array}$ \\
\hline Person 1 & 60 & 40 & $\mathbf{2 0}$ \\
Person 2 & 60 & 45 & $\mathbf{1 5}$ \\
Person 3 & 60 & 50 & $\mathbf{1 0}$ \\
\hline Total & 180 & 135 & $\mathbf{4 5}$ \\
\hline
\end{tabular}

\begin{tabular}{|l|c|c|c|}
\hline $\begin{array}{c}\text { Other } \\
\text { Group }\end{array}$ & $\begin{array}{c}\text { Endow } \\
\text {-ment } \\
\text { (ECUs) }\end{array}$ & $\begin{array}{c}\text { Allocation } \\
\text { to the } \\
\text { individual } \\
\text { account }\end{array}$ & $\begin{array}{c}\text { Allocation } \\
\text { to the } \\
\text { group } \\
\text { account }\end{array}$ \\
\hline Person 1 & 60 & 50 & $\mathbf{1 0}$ \\
Person 2 & 60 & 60 & $\mathbf{0}$ \\
\hline Person 3 & 60 & 55 & $\mathbf{5}$ \\
\hline
\end{tabular}

Members of your group have allocated a total of 45 ECUs to your group account while members of the other group have allocated 15 ECUs. Thus, the computer will place 45 red tokens and 15 black tokens into the box (60 tokens total). Then the computer will randomly draw one token out of the box. You can see that since your group has contributed more it has a higher chance of receiving the reward - your group will receive the reward 45 out of 60 times. The other group has a lower chance of receiving the reward - 15 out of 60 times.

A group can never guarantee itself the reward. However, by increasing your bid, you can increase your group's chance of receiving the reward. If your group receives the reward, 120 ECUs will be divided equally among the members of your group, i.e., you and the other 2 members of your group will receive 40 ECUs each. 


\section{YOUR EARNINGS}

\section{EARNINGS IN EACH PERIOD:}

After all participants have made their decisions, your earnings for the period are calculated.

3) For each ECU in your individual account, you will earn 1 ECU in return. So, if you keep all 60 ECUs that you are endowed with in your individual account you will earn 60 ECUs.

4) You can also earn some ECUs from your group account. After all bids are made, the computer uses the random draw process described above to decide which group wins the reward. If your group wins the reward, you will earn $\mathbf{4 0}$ ECUs from your group account in addition to your earnings from your individual account. Each of the other 2 members of your group will also earn 40 ECUs from the group account. If the other group wins the reward, you and the other 2 members of your group receive nothing from your group account. In this event, your period earnings will be equal to your earnings from your individual account.

Your period earnings are the sum of the earnings from your individual account and the earnings from your group account. The following example illustrates the calculation of period earnings.

Note: The following example is for illustrative purposes only.

\section{Example 2. Period Earnings}

In Example 1, your group allocated a total of 45 ECUs while other group allocated a total of 15 ECUs to the group accounts. Let's say the computer made a random draw and your group received the reward. Thus, all the members of your group receive 40 ECUs each from your group account plus earnings from their individual accounts. All members of the other group receive earnings only from their individual accounts, since their group did not receive the reward. The calculation of the total earnings is shown in Table 2 below. 
Table 2 - Calculation of earnings for both groups

\begin{tabular}{|l|c|c|c|}
\hline $\begin{array}{c}\text { Your } \\
\text { group }\end{array}$ & $\begin{array}{c}\text { Earnings } \\
\text { from } \\
\text { group } \\
\text { account }\end{array}$ & $\begin{array}{c}\text { Earnings } \\
\text { from } \\
\text { individual } \\
\text { account }\end{array}$ & $\begin{array}{c}\text { Total period } \\
\text { earnings }\end{array}$ \\
\hline Person 1 & $\mathbf{4 0}$ & $\mathbf{4 0}$ & $40+40=\mathbf{8 0}$ \\
Person 2 & $\mathbf{4 0}$ & $\mathbf{4 5}$ & $40+45=\mathbf{8 5}$ \\
\hline Total & $\mathbf{1 2 0}$ & $\mathbf{1 3 5}$ & $40+50=\mathbf{9 0}$ \\
\hline
\end{tabular}

\begin{tabular}{|l|c|c|c|}
\hline $\begin{array}{c}\text { Other } \\
\text { group }\end{array}$ & $\begin{array}{c}\text { Earnings } \\
\text { from } \\
\text { group } \\
\text { account }\end{array}$ & $\begin{array}{c}\text { Earnings } \\
\text { from } \\
\text { individual } \\
\text { account }\end{array}$ & $\begin{array}{c}\text { Total } \\
\text { period } \\
\text { earnings }\end{array}$ \\
\hline Person 1 & $\mathbf{0}$ & $\mathbf{5 0}$ & $\mathbf{5 0}$ \\
Person 2 & $\mathbf{0}$ & $\mathbf{6 0}$ & $\mathbf{6 0}$ \\
Person 3 & $\mathbf{0}$ & $\mathbf{5 5}$ & $\mathbf{5 5}$ \\
\hline Total & $\mathbf{0}$ & $\mathbf{1 6 5}$ & 165 \\
\hline
\end{tabular}

\section{EARNINGS FROM THE EXPERIMENT:}

At the end of the experiment we will randomly choose $\mathbf{5}$ of the 20 periods for actual payment using a computer program. You will be paid the sum of the earnings in each of these 5 periods. These earnings will be converted to cash at the exchange rate mentioned earlier and will be paid at the end of the experiment.

Note: All participants in this session will be paid for the same 5 periods.

\section{OUTCOME SCREEN}

At the end of each period, the total number of ECUs in the two groups' accounts, which group received the reward, your earnings from your individual and your group accounts, and your total earnings for the period are reported on the outcome screen as shown below. Please record your results for the period on your record sheet under the appropriate heading. 


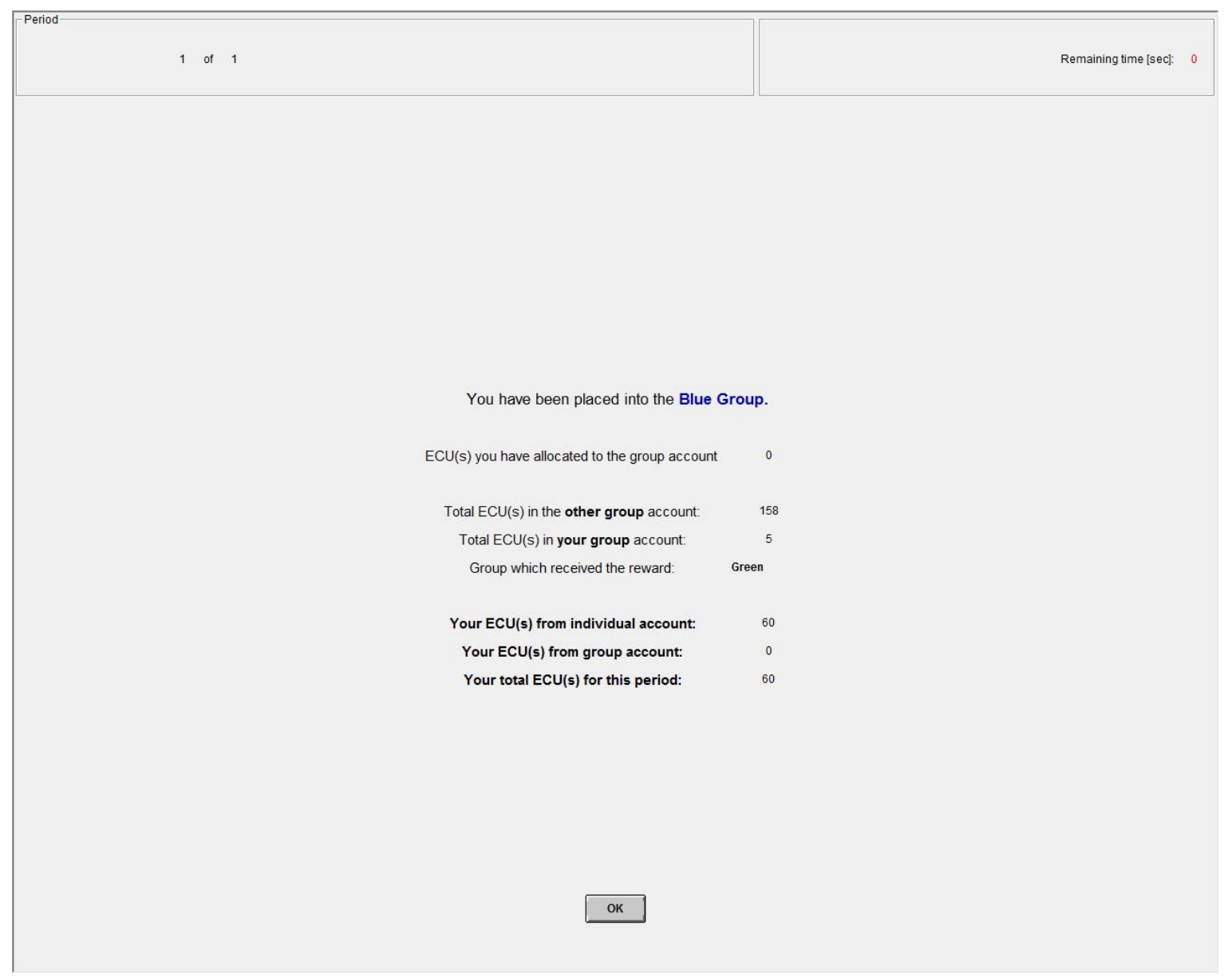

\section{QUESTIONS TO HELP YOU BETTER UNDERSTAND THE DECISION TASKS}

When everyone has finished reading the instructions, and before the experiment begins, we will ask you a few questions regarding the decisions you will make in the experiment. The questions will help you understand the calculation of your earnings and ensure that you have understood the instructions. 
Personal Record Sheet

\begin{tabular}{|c|c|c|c|}
\hline Period & $\begin{array}{l}\text { Earnings from } \\
\text { individual account }\end{array}$ & $\begin{array}{l}\text { Earnings from } \\
\text { your group } \\
\text { account }\end{array}$ & $\begin{array}{l}\text { Total earnings } \\
\text { for this period }\end{array}$ \\
\hline 1 & & & \\
\hline 2 & & & \\
\hline 3 & & & \\
\hline 4 & & & \\
\hline 5 & & & \\
\hline 6 & & & \\
\hline 7 & & & \\
\hline 8 & & & \\
\hline 9 & & & \\
\hline 10 & & & \\
\hline 11 & & & \\
\hline 12 & & & \\
\hline 13 & & & \\
\hline 14 & & & \\
\hline 15 & & & \\
\hline 16 & & & \\
\hline 17 & & & \\
\hline 18 & & & \\
\hline 19 & & & \\
\hline 20 & & & \\
\hline
\end{tabular}


Total Earnings

\begin{tabular}{|l|l|}
\hline Period Chosen & Total earnings for this period \\
\hline & \\
\hline & \\
\hline & \\
\hline & \\
\hline & \\
\hline Total & $=$ \\
\hline
\end{tabular}

Sum earnings from table above:

Divide earnings by conversion rate:

$\div \quad 25$

Earnings in British Pounds:

$\underline{£}$

Earnings from Showing up:

$£ 2$ (2)

Total payment received: (1)+(2)

$£$ 


\section{QUIZ}

2. Does group composition change across periods in the experiment?

Ans. Yes No

\section{Questions 2 to 6 apply to the following information.}

In a given period, suppose the members of your group and the other group chose to allocate their ECUs to the group account as it is shown in the table below.

\begin{tabular}{|l|c|c|c|}
\hline $\begin{array}{c}\text { Your } \\
\text { group }\end{array}$ & Endow- & $\begin{array}{c}\text { Allocation } \\
\text { to the } \\
\text { individual } \\
\text { account }\end{array}$ & $\begin{array}{c}\text { Allocation } \\
\text { to the } \\
\text { group } \\
\text { account }\end{array}$ \\
\hline Person 1 & 60 & 35 & 25 \\
Person 2 & 60 & 60 & 0 \\
\hline Total & 180 & 150 & 30 \\
\hline
\end{tabular}

\begin{tabular}{|l|c|c|c|}
\hline $\begin{array}{c}\text { Other } \\
\text { group }\end{array}$ & Endow- & $\begin{array}{c}\text { Allocation } \\
\text { to the } \\
\text { individual } \\
\text { account }\end{array}$ & $\begin{array}{c}\text { Allocation } \\
\text { to the } \\
\text { group } \\
\text { account }\end{array}$ \\
\hline Person 1 & 60 & 40 & 20 \\
Person 2 & 60 & 40 & 20 \\
\hline Total & 180 & 130 & 50 \\
\hline
\end{tabular}

2. How many total ECUs will the computer place into the box?

Ans.

3. If the computer makes a random draw out of the box what is the chance of your group receiving the reward?

Ans. out of

4. If the computer makes a random draw out of the box what is the chance of the other group receiving the reward? 
Ans.

out of

5. If you are Person 1 in your group and your group did not receive the reward what are your period earnings?

Ans.

6. If you are Person 2 in your group and your group received the reward what are your period earnings?

Ans.

\section{EXPLANATIONS FOR OUIZ ANSWERS}

2. Does group composition change across periods in the experiment? Correct answer: No

\section{Questions 2 to 6 apply to the following information.}

In a given period, suppose the members of your group and the other group chose to allocate their ECUs to the group account as it is shown in the table below.

\begin{tabular}{|l|c|c|c|}
\hline $\begin{array}{c}\text { Your } \\
\text { group }\end{array}$ & Endow- & $\begin{array}{c}\text { Allocation } \\
\text { to the } \\
\text { individual } \\
\text { account }\end{array}$ & $\begin{array}{c}\text { Allocation } \\
\text { to the } \\
\text { group } \\
\text { account }\end{array}$ \\
\hline Person 1 & 60 & 35 & 25 \\
Person 3 & 60 & 55 & 5 \\
\hline Total & 180 & 150 & 30 \\
\hline
\end{tabular}

\begin{tabular}{|l|c|c|c|}
\hline $\begin{array}{c}\text { Other } \\
\text { group }\end{array}$ & Endow- & $\begin{array}{c}\text { Allocation } \\
\text { to the } \\
\text { individual } \\
\text { account }\end{array}$ & $\begin{array}{c}\text { Allocation } \\
\text { to the } \\
\text { group } \\
\text { account }\end{array}$ \\
\hline Person 1 & 60 & 40 & 20 \\
Person 2 & 60 & 40 & 20 \\
\hline Total & 180 & 130 & 50 \\
\hline
\end{tabular}


2. How many total ECUs will the computer place into the box? Correct answer: 80

Allocation to the group account by your group and by the other group, i.e., 30 from your group PLUS 50 from the other group.

3. If the computer makes a random draw out of the box what is the chance of your group receiving the reward? - Correct answer: 30 out of 80

Out of a total of 80 tokens, 30 belong to your group. Thus the chance of your group winning any random draw of one token from the box is 30 tokens out of 80 .

4. If the computer makes a random draw out of the box what is the chance of the other group receiving the reward? - Correct answer: 50 out of 80

Out of a total of 80 tokens, 50 belong to the other group. Thus the chance of the other group winning any random draw of one token from the box is 50 tokens out of 80 .

5. If you are Person 1 in your group and your group did not receive the reward what are your period earnings? Correct answer: 35

Since your group did not win the reward, your earnings from the group account for this period are zero. So, your period earnings are equal to your earnings from your individual account. From the above table, this is equal to 35 ECUs, your allocation to your individual account.

6. If you are Person 2 in your group and your group received the reward what are your period earnings? Correct answer: 100

Since your group did win the reward, your earnings from the group account for this period are 40 ECUs (Your group wins 120 ECUs which are split equally among all 3 of you). So, your period earnings are equal to your earnings from your individual account plus 40 ECUs (your earnings from the group account). From the above table, your allocation to your individual account is 60 . Thus your total period earnings are $60+40=100$ ECUs. 


\section{Instructions for the Race treatment}

\section{GENERAL INSTRUCTIONS}

This is an experiment in the economics of decision making. The instructions are simple. If you follow them closely and make appropriate decisions, you can earn an appreciable amount of money.

Experimental Currency is used in the experiment and your decisions and earnings will be recorded in Experimental Currency Units (ECUs). At the end of today's experiment, you will be paid in private and in cash. ECUs will be converted to Pound Sterling at a rate of _25_ECUs to _1_ British Pound.

It is extremely important that you remain silent and do not look at other people's work. If you have any questions, or need assistance of any kind, please raise your hand and an experimenter will come to you. If you talk, laugh, exclaim out loud, etc., you will be asked to leave and you will not be paid. We expect and appreciate your cooperation.

\section{EXPERIMENTAL INSTRUCTIONS}

\section{YOUR DECISION}

The experiment consists of $\mathbf{2 0}$ decision-making periods. At the beginning of the experiment, you will be anonymously placed into a group of $\mathbf{3}$ people. You will be placed in either an 'East Asian' group or a 'Caucasian-White' group. If you are placed in an East Asian group, all 3 members of your group will be East Asian. If you are placed in a Caucasian-White group, all 3 members of your group will be Caucasian-White. Your group will then be anonymously matched with another group of 3 people. If you are placed into a Caucasian-White group, then your group will be matched with an East Asian group. If you are placed into an East Asian group, then your group will be matched with a Caucasian-White group. In each period your group as well as the group your group is matched with will remain the same. However, at no point will you know who your group members are or who the members of the other group are. Also, you will not know any other information about the members of your group or the members of the other group. 
Each period you will be given an initial endowment of $\mathbf{6 0}$ ECUs. You will then decide how much to allocate to a group account or an individual account. On your screen, you will be asked to enter your allocation to the group account. You may allocate any integer number of ECUs between, and including, $\mathbf{0}$ and $\mathbf{6 0}$. Any ECUs you do not allocate to the group account will automatically be allocated to your individual account. An example of your decision screen is shown below.

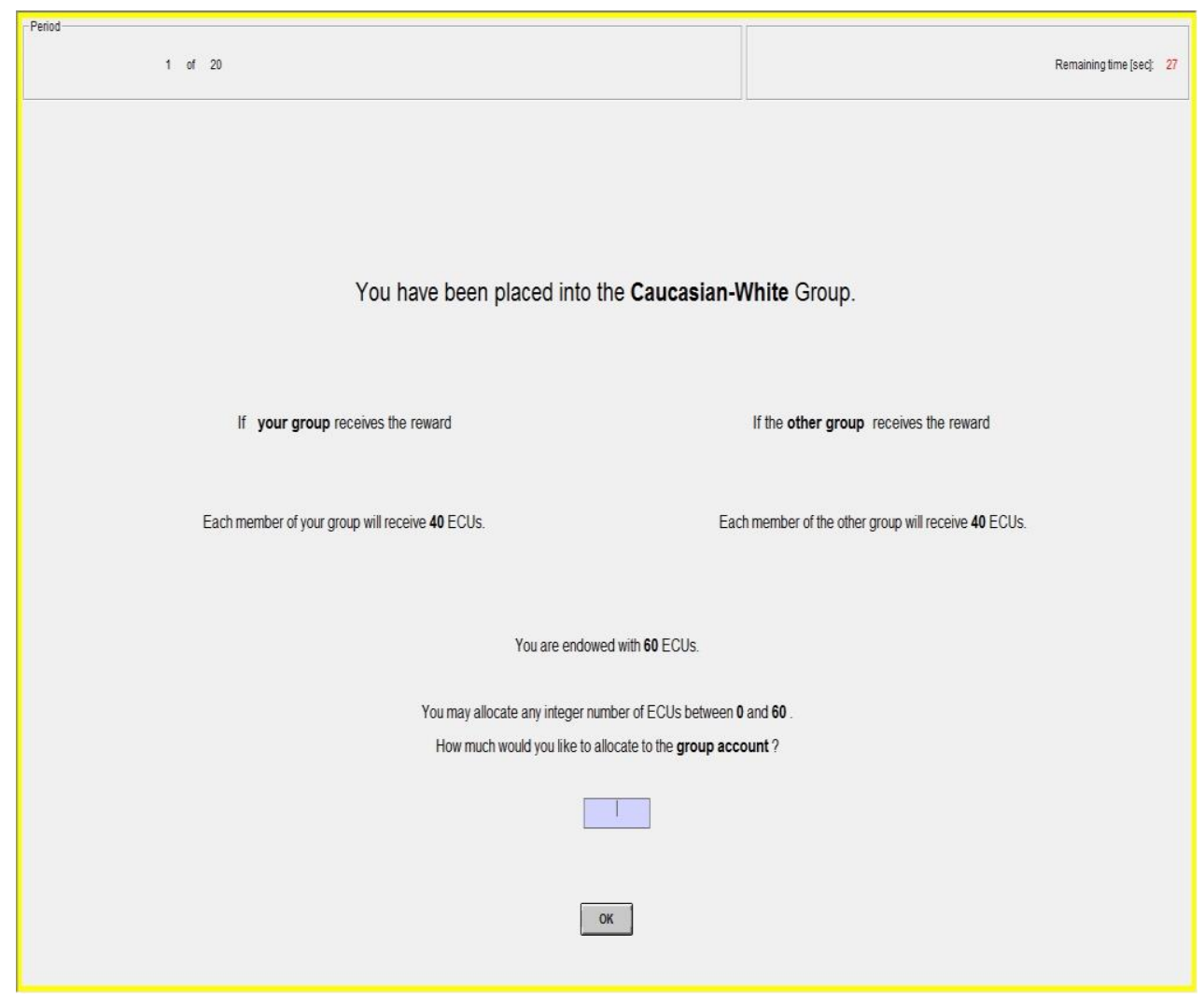

At the end of each period, either your group or the other group will receive a reward of $\mathbf{1 2 0}$ ECUs (40 ECUs per group member). In each period, only one of the two groups can obtain the reward. By contributing to your group account you increase the chance of receiving the reward for your group. If the total number of ECUs in your group account exceeds the total number of ECUs in the other group's account, your group has a higher chance of receiving the reward.

The computer will assign the reward either to your group or to the other group, via a random draw that depends on the total allocation in the group accounts by the two groups. Below is a hypothetical example used to illustrate how the computer makes a random draw to decide which group wins the reward. 
Note: The following example is for illustrative purposes only.

\section{Example 1. Random Draw}

Think of the random draw in the following way. For each ECU in your group's account the computer puts 1 red token into a box and for each ECU in the other group's account the computer puts 1 black token. Then the computer randomly draws one token out of the box. If the drawn token is red then your group receives the reward, if the drawn token is black then the other group receives the reward. Suppose that members of both groups have allocated their ECUs in the following way (as shown in Table 1 below).

Table 1 - Allocation of ECUs by members of both groups

\begin{tabular}{|l|c|c|c|}
\hline $\begin{array}{c}\text { Your } \\
\text { Group }\end{array}$ & $\begin{array}{c}\text { Endow- } \\
\text { ment } \\
\text { (ECUs) }\end{array}$ & $\begin{array}{c}\text { Allocation } \\
\text { to the } \\
\text { individual } \\
\text { account }\end{array}$ & $\begin{array}{c}\text { Allocation } \\
\text { to the } \\
\text { group } \\
\text { account }\end{array}$ \\
\hline Person 1 & 60 & 40 & $\mathbf{2 0}$ \\
Person 2 & 60 & 45 & $\mathbf{1 5}$ \\
Person 3 & 60 & 50 & $\mathbf{1 0}$ \\
\hline Total & 180 & 135 & $\mathbf{4 5}$ \\
\hline
\end{tabular}

\begin{tabular}{|l|c|c|c|}
\hline $\begin{array}{c}\text { Other } \\
\text { Group }\end{array}$ & $\begin{array}{c}\text { Endow- } \\
\text { ment } \\
\text { (ECUs) }\end{array}$ & $\begin{array}{c}\text { Allocation } \\
\text { to the } \\
\text { individual } \\
\text { account }\end{array}$ & $\begin{array}{c}\text { Allocation } \\
\text { to the } \\
\text { group } \\
\text { account }\end{array}$ \\
\hline Person 1 & 60 & 50 & $\mathbf{1 0}$ \\
Person 2 & 60 & 60 & $\mathbf{0}$ \\
Person 3 & 60 & 55 & $\mathbf{5}$ \\
\hline Total & 180 & 165 & $\mathbf{1 5}$ \\
\hline
\end{tabular}

Members of your group have allocated a total of 45 ECUs to your group account while members of the other group have allocated 15 ECUs. Thus, the computer will place 45 red tokens and 15 black tokens into the box (60 tokens total). Then the computer will randomly draw one token out of the box. You can see that since your group has contributed more it has a higher chance of receiving the reward - your group will receive the reward 45 out of 60 times. The other group has a lower chance of receiving the reward - 15 out of 60 times.

A group can never guarantee itself the reward. However, by increasing your contribution, you can increase your group's chance of receiving the reward. If your group receives the reward, 120 ECUs will be divided equally among the members of your group, i.e., you and the other 2 members of your group will receive 40 ECUs each. 


\section{YOUR EARNINGS}

\section{EARNINGS IN EACH PERIOD:}

After all participants have made their decisions, your earnings for the period are calculated.

1) For each ECU in your individual account, you will earn 1 ECU in return. So, if you keep all 60 ECUs that you are endowed with in your individual account you will earn 60 ECUs.

2) You can also earn some ECUs from your group account. After all contributions are made, the computer uses the random draw process described above to decide which group wins the reward. If your group wins the reward, you will earn $\mathbf{4 0}$ ECUs from your group account in addition to your earnings from your individual account. Each of the other 2 members of your group will also earn 40 ECUs from the group account. If the other group wins the reward, you and the other 2 members of your group receive nothing from your group account. In this event, your period earnings will be equal to your earnings from your individual account.

Your period earnings are the sum of the earnings from your individual account and the earnings from your group account. The following example illustrates the calculation of period earnings.

Note: The following example is for illustrative purposes only.

\section{Example 2. Period Earnings}

In Example 1, your group allocated a total of 45 ECUs while other group allocated a total of 15 ECUs to the group accounts. Let's say the computer made a random draw and your group received the reward. Thus, all the members of your group receive 40 ECUs each from your group account plus earnings from their individual accounts. All members of the other group receive earnings only from their individual accounts, since their group did not receive the reward. The calculation of the total earnings is shown in Table 2 below. 
Table 2 - Calculation of earnings for both groups

\begin{tabular}{|l|c|c|c|}
\hline $\begin{array}{c}\text { Your } \\
\text { group }\end{array}$ & $\begin{array}{c}\text { Earnings } \\
\text { from } \\
\text { group } \\
\text { account }\end{array}$ & $\begin{array}{c}\text { Earnings } \\
\text { from } \\
\text { individual } \\
\text { account }\end{array}$ & $\begin{array}{c}\text { Total period } \\
\text { earnings }\end{array}$ \\
\hline Person 1 & $\mathbf{4 0}$ & $\mathbf{4 0}$ & $40+40=\mathbf{8 0}$ \\
Person 2 & $\mathbf{4 0}$ & $\mathbf{4 5}$ & $40+45=\mathbf{8 5}$ \\
Person 3 & $\mathbf{4 0}$ & $\mathbf{5 0}$ & $40+50=\mathbf{9 0}$ \\
\hline Total & $\mathbf{1 2 0}$ & $\mathbf{1 3 5}$ & 255 \\
\hline
\end{tabular}

\begin{tabular}{|l|c|c|c|}
\hline Other \\
group & $\begin{array}{c}\text { Earnings } \\
\text { from } \\
\text { group } \\
\text { account }\end{array}$ & $\begin{array}{c}\text { Earnings } \\
\text { from } \\
\text { individual } \\
\text { account }\end{array}$ & $\begin{array}{c}\text { Total } \\
\text { period } \\
\text { earnings }\end{array}$ \\
\hline Person 1 & $\mathbf{0}$ & $\mathbf{5 0}$ & $\mathbf{5 0}$ \\
Person 2 & $\mathbf{0}$ & $\mathbf{6 0}$ & $\mathbf{6 0}$ \\
Person 3 & $\mathbf{0}$ & $\mathbf{5 5}$ & $\mathbf{5 5}$ \\
\hline Total & $\mathbf{0}$ & $\mathbf{1 6 5}$ & 165 \\
\hline
\end{tabular}

\section{EARNINGS FROM THE EXPERIMENT:}

At the end of the experiment we will randomly choose $\mathbf{5}$ of the 20 periods for actual payment using a computer program. You will be paid the sum of the earnings in each of these 5 periods. These earnings will be converted to cash at the exchange rate mentioned earlier and will be paid at the end of the experiment.

Note: All participants in this session will be paid for the same 5 periods.

\section{OUTCOME SCREEN}

At the end of each period, the total number of ECUs in the two groups' accounts, which group received the reward, your earnings from your individual and your group accounts, and your total earnings for the period are reported on the outcome screen as shown below. Please record your results for the period on your record sheet under the appropriate heading. 


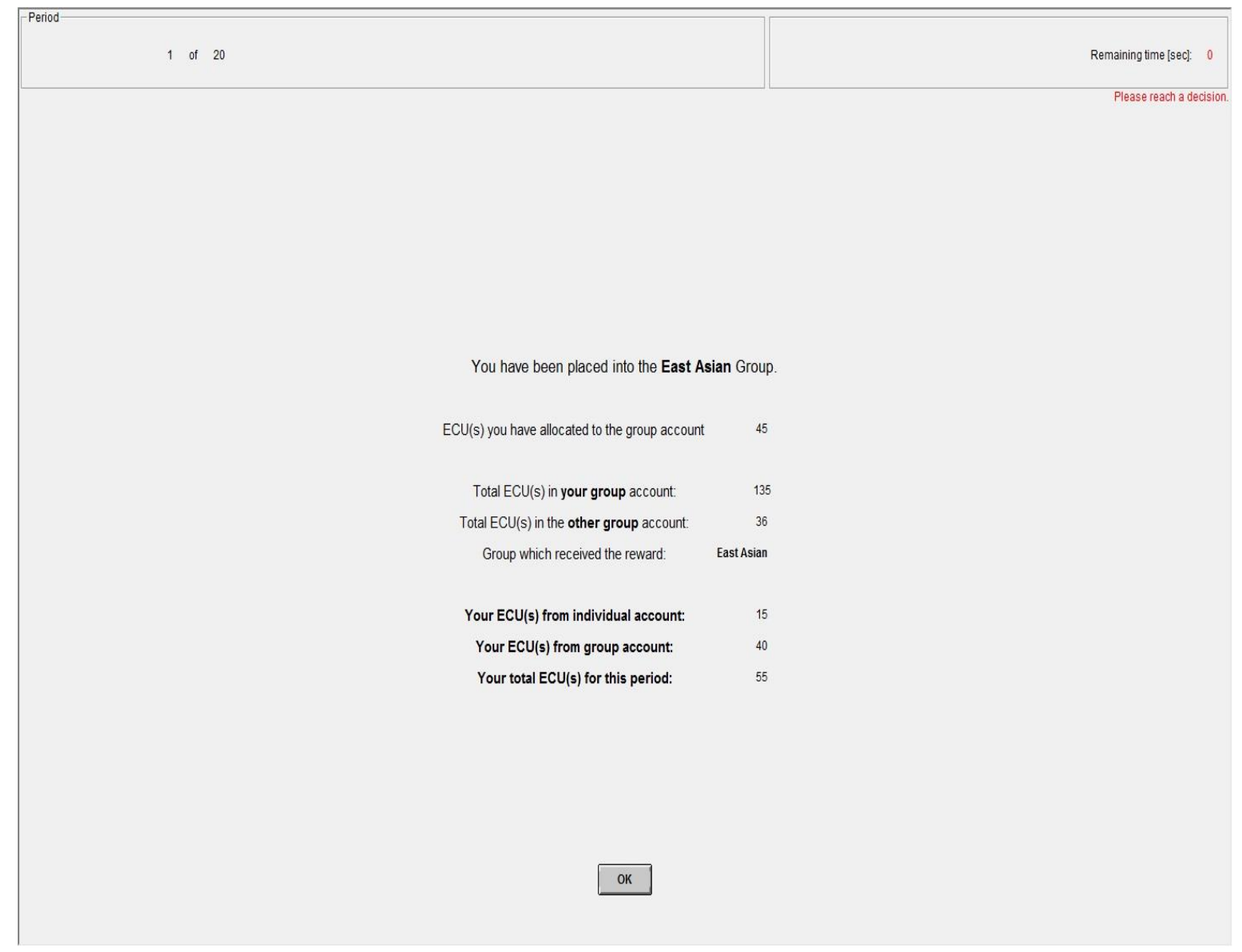

\section{QUESTIONS TO HELP YOU BETTER UNDERSTAND THE DECISION TASKS}

When everyone has finished reading the instructions, and before the experiment begins, we will ask you a few questions regarding the decisions you will make in the experiment. The questions will help you understand the calculation of your earnings and ensure that you have understood the instructions. 
Personal Record Sheet

\begin{tabular}{|c|c|c|c|}
\hline Period & $\begin{array}{l}\text { Earnings from } \\
\text { individual account }\end{array}$ & $\begin{array}{l}\text { Earnings from } \\
\text { your group } \\
\text { account }\end{array}$ & $\begin{array}{l}\text { Total earnings } \\
\text { for this period }\end{array}$ \\
\hline \multicolumn{4}{|l|}{1} \\
\hline \multicolumn{4}{|l|}{2} \\
\hline \multicolumn{4}{|l|}{3} \\
\hline \multicolumn{4}{|l|}{4} \\
\hline \multicolumn{4}{|l|}{5} \\
\hline \multicolumn{4}{|l|}{6} \\
\hline \multicolumn{4}{|l|}{7} \\
\hline \multicolumn{4}{|l|}{8} \\
\hline \multicolumn{4}{|l|}{9} \\
\hline \multicolumn{4}{|l|}{10} \\
\hline \multicolumn{4}{|l|}{11} \\
\hline \multicolumn{4}{|l|}{12} \\
\hline \multicolumn{4}{|l|}{13} \\
\hline \multicolumn{4}{|l|}{14} \\
\hline \multicolumn{4}{|l|}{15} \\
\hline \multicolumn{4}{|l|}{16} \\
\hline \multicolumn{4}{|l|}{17} \\
\hline \multicolumn{4}{|l|}{18} \\
\hline \multicolumn{4}{|l|}{19} \\
\hline 20 & & & \\
\hline
\end{tabular}


Total Earnings

\begin{tabular}{|l|l|}
\hline Period Chosen & Total earnings for this period \\
\hline & \\
\hline & \\
\hline & \\
\hline & \\
\hline Total & $=$ \\
\hline
\end{tabular}

Sum earnings from table above:

Divide earnings by conversion rate:

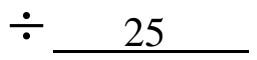

Earnings in British Pounds:

$£$

Earnings from Showing up:

$£ 2$

Total payment received: (1)+(2)

$£$ 


\section{QUIZ}

3. Does group composition change across periods in the experiment?

Ans. Yes No

\section{Questions 2 to 6 apply to the following information.}

In a given period, suppose the members of your group and the other group chose to allocate their ECUs to the group account as it is shown in the table below.

\begin{tabular}{|l|c|c|c|}
\hline $\begin{array}{c}\text { Your } \\
\text { group }\end{array}$ & $\begin{array}{c}\text { Endow- } \\
\text { ment }\end{array}$ & $\begin{array}{c}\text { Allocation } \\
\text { to the } \\
\text { individual } \\
\text { account }\end{array}$ & $\begin{array}{c}\text { Allocation } \\
\text { to the } \\
\text { group } \\
\text { account }\end{array}$ \\
\hline Person 1 & 60 & 35 & 25 \\
Person 2 & 60 & 60 & 0 \\
Person 3 & 60 & 55 & 5 \\
\hline Total & 180 & 150 & 30 \\
\hline
\end{tabular}

\begin{tabular}{|l|c|c|c|}
\hline $\begin{array}{c}\text { Other } \\
\text { group }\end{array}$ & $\begin{array}{c}\text { Endow- } \\
\text { ment }\end{array}$ & $\begin{array}{c}\text { Allocation } \\
\text { to the } \\
\text { individual } \\
\text { account }\end{array}$ & $\begin{array}{c}\text { Allocation } \\
\text { to the } \\
\text { group } \\
\text { account }\end{array}$ \\
\hline Person 1 & 60 & 40 & 20 \\
Person 2 & 60 & 40 & 20 \\
Person 3 & 60 & 50 & 10 \\
\hline Total & 180 & 130 & 50 \\
\hline
\end{tabular}

2. How many total ECUs will the computer place into the box?

Ans.

3. If the computer makes a random draw out of the box what is the chance of your group receiving the reward?

Ans.

out of

4. If the computer makes a random draw out of the box what is the chance of the other group receiving the reward?

Ans.

out of 
5. If you are Person 1 in your group and your group did not receive the reward what are your period earnings?

Ans.

6. If you are Person 2 in your group and your group received the reward what are your period earnings?

Ans.

\section{EXPLANATIONS FOR QUIZ ANSWERS}

3. Does group composition change across periods in the experiment? Correct answer: No

\section{Questions 2 to 6 apply to the following information.}

In a given period, suppose the members of your group and the other group chose to allocate their ECUs to the group account as it is shown in the table below.

\begin{tabular}{|l|c|c|c|}
\hline $\begin{array}{c}\text { Your } \\
\text { group }\end{array}$ & $\begin{array}{c}\text { Endow- } \\
\text { ment } \\
\text { Person 1 }\end{array}$ & $\begin{array}{c}\text { Allocation } \\
\text { to the } \\
\text { individual } \\
\text { account }\end{array}$ & $\begin{array}{c}\text { Allocation } \\
\text { to the } \\
\text { group } \\
\text { account }\end{array}$ \\
\hline Person 2 & 60 & 35 & 25 \\
Person 3 & 60 & 55 & 5 \\
\hline Total & 180 & 150 & 30 \\
\hline
\end{tabular}

\begin{tabular}{|l|c|c|c|}
\hline $\begin{array}{c}\text { Other } \\
\text { group }\end{array}$ & $\begin{array}{c}\text { Endow- } \\
\text { ment }\end{array}$ & $\begin{array}{c}\text { Allocation } \\
\text { to the } \\
\text { individual } \\
\text { account }\end{array}$ & $\begin{array}{c}\text { Allocation } \\
\text { to the } \\
\text { group } \\
\text { account }\end{array}$ \\
\hline Person 1 & 60 & 40 & 20 \\
Person 2 & 60 & 40 & 20 \\
Person 3 & 60 & 50 & 10 \\
\hline Total & 180 & 130 & 50 \\
\hline
\end{tabular}


2. How many total ECUs will the computer place into the box? Correct answer: 80 Allocation to the group account by your group and by the other group, i.e., 30 from your group PLUS 50 from the other group.

3. If the computer makes a random draw out of the box what is the chance of your group receiving the reward? - Correct answer: 30 out of 80

Out of a total of 80 tokens, 30 belong to your group. Thus the chance of your group winning any random draw of one token from the box is 30 tokens out of 80 .

4. If the computer makes a random draw out of the box what is the chance of the other group receiving the reward? - Correct answer: 50 out of 80

Out of a total of 80 tokens, 50 belong to the other group. Thus the chance of the other group winning any random draw of one token from the box is 50 tokens out of 80 .

5. If you are Person 1 in your group and your group did not receive the reward what are your period earnings? Correct answer: 35

Since your group did not win the reward, your earnings from the group account for this period are zero. So, your period earnings are equal to your earnings from your individual account. From the above table, this is equal to 35 ECUs, your allocation to your individual account.

6. If you are Person 2 in your group and your group received the reward what are your period earnings? Correct answer: 100

Since your group did win the reward, your earnings from the group account for this period are 40 ECUs (Your group wins 120 ECUs which are split equally among all 3 of you). So, your period earnings are equal to your earnings from your individual account plus 40 ECUs (your earnings from the group account). From the above table, your allocation to your individual account is 60 . Thus your total period earnings are $60+40=100$ ECUs. 